Review

\title{
Why People (Do Not) Adopt the Private Precautionary and Mitigation Measures: A Review of the Issue from the Perspective of Recent Flood Risk Research
}

Ivan Andráško 1,2

Citation: Andráško, I. Why People (Do Not) Adopt the Private

Precautionary and Mitigation Measures: A Review of the Issue from the Perspective of Recent Flood Risk Research. Water 2021, 13, 140.

https://doi.org/10.3390/w13020140

Received: 16 November 2020

Accepted: 5 January 2021

Published: 9 January 2021

Publisher's Note: MDPI stays neutral with regard to jurisdictional clai$\mathrm{ms}$ in published maps and institutional affiliations.

Copyright: $\odot 2021$ by the author. Licensee MDPI, Basel, Switzerland. This article is an open access article distributed under the terms and conditions of the Creative Commons Attribution (CC BY) license (https:// creativecommons.org/licenses/by/ $4.0 /)$.
1 Department of Environmental Geography, Institute of Geonics, The Czech Academy of Sciences, Drobného 28, 60200 Brno, Czech Republic; ivan.andrasko@ugn.cas.cz

2 Department of Ecology and Environmental Sciences, Faculty of Natural Sciences, Constantine the Philosopher University in Nitra, Tr. A. Hlinku 1, 94901 Nitra, Slovakia

\begin{abstract}
Based on the literature review, this paper synthesizes recent state of knowledge on flood risk perception and related human behaviors. The main attention is paid to private precautionary and mitigation measures, and the reasons why these are (not) adopted by agents such as individual households. Results of a wide range of relevant studies are presented and critically examined. The findings are presented within an interpretive framework established during the review process; six key themes (responsibility, risk perception, people and social environment, geography of risk, emotions, theories and conceptual models) and several sub-themes closely related to them were identified by the content/thematic analysis. These were then utilized to overview and discuss particular factors and issues involved, as well as various relevant theoretical underpinnings and conceptual models. The review identifies, illustrates, and addresses not only the consensual views and contradictory findings of flood risk research, but also several related and essential ambiguities, uncertainties, and knowledge gaps. Based on these findings, suggestions for future research are discussed, including the terminological, semantic, methodological, theoretical, and ethical aspects. The paper thus serves two main tasks: (a) It is a useful reference/departure point for those with research interests in topics and issues such as flood risk perception, flood risk protective and mitigation behaviors and measures, or flood risk management in general; and (b) it provides suggestions and incentives for future flood risk research agenda.
\end{abstract}

Keywords: floods; flood risk management; mitigation measures; households; behavior; factors; responsibility; risk perception; experience; emotions; theory; flood risk research

\section{Introduction}

Recent flood risk management (hereafter FRM) is continuously passing through a set of developments, often designated as a "shift" [1-6], or even as a "turn" [7]. First, decreasing importance is attributed to maintaining a very small flood probability [8], to the unattainable absolute flood protection [9], and to the large scale, publicly funded engineering solutions such as dams $[2,10,11]$. Second, increased attention turns to the intertwined nature of a spectrum of natural and societal processes associated with floods [12,13], to concepts such as preparedness, resilience, or vulnerability $[6,14]$, to the concept of shared responsibility [1,10,15-17], and to risk transfer instruments and measures such as flood-risk communication, monitoring and warning systems, or public participation in decision-making, and spatial planning processes [1,2,7,18-20]. In general terms, the older, more "traditional" approaches, mostly relying on the centralized, top-down decisionmaking, and on the technological and technocratic solutions $[3,6,21]$, are continuously complemented - rather than replaced [22]—by newer, "sustainable," "more holistic," "integrated," or "softer" approaches [1,2,4,9,15,23-29]. 
A common part of such developments are the proclaimed expectations of experts, governments, and other officials and authorities that subjects/agents having any kind of direct relationship to the flood-prone areas (or even those without such a relationship) will, due to the presence of the constant flood threat and the inability of public measures to assure the complete protection, engage actively in flood preparedness and mitigation activities. Thus, various public and private agents, such as diverse stakeholders, local property owners, inhabitants, or individual levels, and representatives of decision-making, are now all, in an increasing and "shared" manner, expected to take their part in prevention, mitigation, recovery, and other floods-related tasks and processes $[6,16,18,30]$. Among these agents the individual households seem to be "the most prominent target group" [7] (p. 3) of such expectations.

Yet, as the pertinent literature and findings (see below) show, the "expectancy part" of the equation does not meet up with appropriate reactions, or what could be called a corresponding "behavioral part" (the term reflects its basis in empirical observations of what particular agents do, or do not do). In other words, most people, including those directly endangered by floods, seem to be reluctant toward participating actively in tackling the threats and damages associated with floods. The existence of such "underreaction" [31] (p. 103) or "policy-practice gap" [2] (p. 331) was recently reported by a number of studies $[15,30,32-35]$. The prime example can serve here the private precautionary and mitigation measures: the adoption of these measures by individual households has been recognized as being essential for handling floods $[5,17,36-40]$ and reducing the floods-related damages and losses [7,31,41,42], and there is a variety of such measures at hand, including those more and less demanding (high- and low-cost), preventive and reactive, individual and community based, one-time and repetitive, or of wet and dry flood-proofing $[2,7,16,17,22,31,34,37,41-53]$. Yet, as regularly observed, inactivity/passivity, deficient familiarity with the measures, their underestimation (or even ridiculing), and lack of their uptake tend to prevail $[2,16,33,39,45,54-56]$. If some of these measures are adopted, those minor/less costly ones are preferred by people, and reactive strategies and responses associated with the immediate threat prevail over prevention and general preparedness $[2,22,44-47,51,57,58]$. Put simply, most people still seem to believe that somebody is obliged to help them [46], they tend to favor the so-called non-protective responses (see Section 4.2), and there remains a common unwillingness and reluctance to engage in mitigation activities [2].

\section{Aim and Structure of This Paper}

Due to its significance from the viewpoint of recent FRM, the issue of what and how affects or drives human decision-making processes and actual activities associated with floods, or, put more simply, why people (do not) engage in floods-related mitigation activities, seems to be of special relevance for the flood risk research endeavor. Moreover, in addition to the explication task, the prediction of human behaviors, the options of channeling these behaviors toward desired ends, but also the specification of such desired ends (for example, community resilience or sustainable FRM) represent important parts of the research efforts as well.

The range of related knowledge collected, produced, and provided by current flood risk research is already an immense one, and naturally calls for review work and systematization. Yet, because of their mostly empirical focus and specific theoretical and methodological underpinnings, most of the relevant studies present only a partial picture of the state of knowledge related to the issue under consideration.

This paper aims at filling this gap. Thus, with the main focus upon the private precautionary and mitigation measures, and the reasons why these measures are (not) adopted by individual households, this paper overviews and synthesizes literature and recent state of knowledge on flood risk perception and flood risk-related human behaviors. Results and findings of a wide range of relevant studies are presented and critically examined. The findings are organized into several key themes and sub-themes identified 
as the key issues of concern during a review procedure (see Section 2), and utilized to discuss the particular factors, empirical findings, and theories involved. Concurring and conflicting views, ambiguities, uncertainties, and knowledge gaps are identified within the recent flood risk research. Finally, the paper proposes a number of suggestions for future flood risk research agenda.

To make the body of related findings and views clearer and more comprehensible, the themes and issues of concern are organized and discussed in the following order:

1. After the introductory part (Section 1), and the description of the review procedures, methods, and materials used (Section 2), the first thoroughly discussed is the topic of "shared responsibility" (Section 3), the one which is central to the "new" FRM. Further explored are the related issues of responsibility transfer and the roles the governments, various authorities and public protection measures play in it. This part of the paper concludes with an overview of another important aspect of the responsibility issue, namely the one of financial resources and funding of flood protection.

2. As important, and closely interrelated factors of the floods-related behaviors are commonly considered the risk perception, flood awareness, and information availability. Therefore these are dealt with in a separate part of the paper (Section 4). The related issues of cognitive biases and evaluations of the flood threat, and potential consequences of floods within wider contexts of people's everyday lives, are discussed here as well.

3. Another theme (Section 5) covers particular characteristics of people (including their memories, experience, and socio-demographic characteristics) and their social environment, and the ways these are linked with people's views of floods and responses to them.

4. Factors of location and the adaptive strategies of relocation/moving out of the endangered areas are reviewed in the next part of the paper (Section 6); reasons why people (move to) live in flood-prone areas are examined here as well.

5. The issue of emotions and their impact on floods-related behaviors is of growing importance in flood risk research. That is why several emotional responses to floods, such as fear or anger, are discussed in this paper (Section 7).

6. There are several theories and conceptual models identifying/establishing links between particular factors associated with flood risk, and explaining what people do (or do not do) in relation to risks such as floods; the following part of the paper (Section 8) deals with these theories, offering their overview, discussion regarding their different classifications and examples of particular theoretical underpinnings.

7. The penultimate part of the paper (Section 9) summarizes and overviews the findings, and points to several relevant consensual and contradictory views, ambiguities, uncertainties, and research gaps. As an essentially important part of this paper, discussion on a variety of suggestions, incentives, and implications for future flood risk research agenda is offered here as well.

8. Finally, Section 10 concludes this paper, pointing out some of its limitations as well.

\section{Procedure, Materials, and Methods}

Because of its broad scope, the findings of this study are based on a semi-systematic literature review. The review procedure involved several subsequent steps:

1. First, the search strategy has been developed, i.e., decisions were made regarding the databases used for searching for the relevant studies, and regarding the search terms. In February 2019, the initial search was conducted, using the international electronic database ScienceDirect and the search terms "floods," "flood risk," "risk perception," "behavior," "households," "protection," "mitigation," "measures." The search generated 1293 results. After restricting the search focus on the research and review articles, this number has been reduced to 773 . Based on a screening of a sample (15\%) of these results (titles, abstracts, keywords), a set of inclusion and exclusion criteria has been established and applied (Table 1). For example, since the review focused on the recent flood risk research, main attention was paid to studies published after 2000. References in other reviews were screened for publications in the additional database (Web of Science). Naturally, 
the relevance of the meanings of the respective terms was also taken into account (for example, "behavior" can be associated not only with humans, but also with materials, fluids, chemical substances etc.,).

Table 1. Inclusion and exclusion criteria used and their description.

\begin{tabular}{cc}
\hline Inclusion/Exclusion Criteria & Descriptions of Criteria \\
\hline Year of publication & Studies published since 2000 \\
\hline Language used & English language \\
\hline Journals & Papers published in peer-reviewed journals \\
\hline Type of the study & $\begin{array}{c}\text { Research and review articles } \\
\text { (review articles prioritized) }\end{array}$ \\
\hline Additional database & References/papers in WOS \\
\hline Full-text & Full-text available/accessible \\
\hline Disciplines/fields of research & No particular restrictions \\
\hline Methods applied & No particular restrictions \\
\hline Titles, keywords, abstracts & $\begin{array}{c}\text { Papers with three or more of the search terms } \\
\text { within the title, keywords and abstract }\end{array}$ \\
\hline Thematic scope and relevance of contents & $\begin{array}{c}\text { Papers dealing with the factors of flood risk } \\
\text { perception and floods-related behaviors from } \\
\text { the viewpoint of flood risk research }\end{array}$ \\
\hline
\end{tabular}

2. Out of the initial search, 82 articles were selected for detailed full-text reading and subjected to content/thematic analysis for preliminary identification of the main recurring themes/issues of concern. This phase also led to the refinement of the main focus of this study (on factors associated with the adoption of private precautionary and mitigation measures).

3. A focused search and snowball method were used to collect further information. The procedure applied involved: checking for references in the initial set of studies (forward and backward searches performed within the reference lists); searching for papers (or other sources such as books or book chapters) dealing with particular themes, sub-themes, or issues (for example, costs, emotions, conceptual models) more thoroughly; searching for studies from various regions of the world and types of countries (for example, middle- and low-income countries); updating and supplementing of relevant findings and information via studies published after the initial search. This focused search was not limited by any special restrictions (for example, in terms of databases or journals used); its main purpose was to attain deeper understanding of the previously identified major themes and the main research issue (including, for example, the roles of pertinent factors). As a result, another 90 studies were included in the review; these were subjected to reading (abstracts, but mostly full-texts) and content analysis as well. This way, the particular key themes were refined, including the identification of their sub-themes; these represent the main issues of concern and the factors of floods-related behavior associated with them. Importantly, they only represent a generalized view of the principal links/associations identified within the research literature, which does not mean they are, in fact, mutually exclusive or isolated. Figures 1-3 characterize the final set of reviewed studies in terms of the time of their publication, spatial focus of research, and methods applied.

4. The main themes and sub-themes identified (Table 2) served as the interpretive framework (or the so-called thematic map) utilized to overview, discuss, and synthesize the theoretical insights and empirical findings of individual studies. 


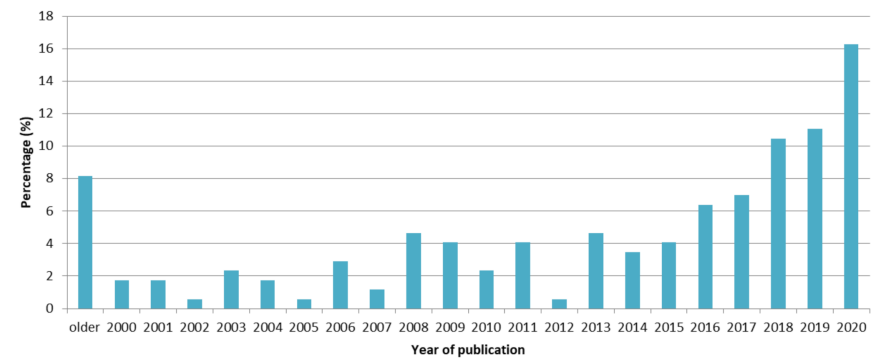

Figure 1. Reviewed studies according to the year of publication.

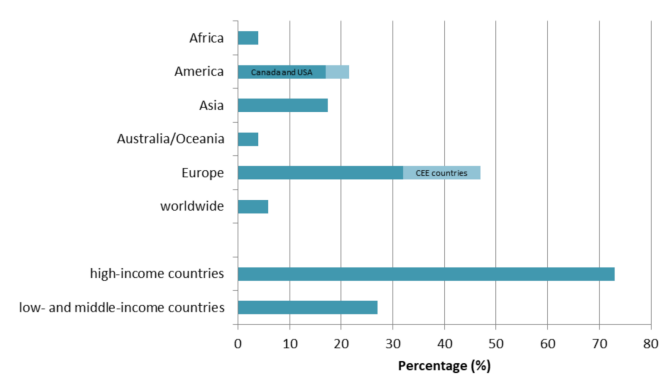

Figure 2. Reviewed studies according to the spatial focus/territories of research.

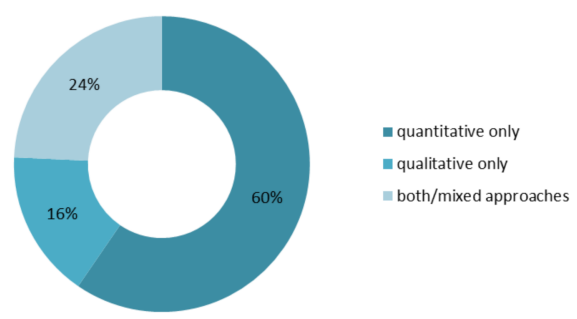

Figure 3. Reviewed studies according to the methods used.

Table 2. Key themes and sub-themes identified across the set of reviewed studies.

\begin{tabular}{|c|c|}
\hline Key Themes/Issues of Concern Identified & $\begin{array}{c}\text { Sub-Themes } \\
\text { (Issues of Concern, Factors of Behavior) }\end{array}$ \\
\hline Responsibility & $\begin{array}{l}\text { Responsibility sharing and transfers } \\
\text { The role of governments and authorities } \\
\text { The role of public/structural protection measures } \\
\text { Financial aspects/issues of funding }\end{array}$ \\
\hline Risk perception & $\begin{array}{c}\text { Threat awareness } \\
\text { Information availability } \\
\text { Cognitive biases and non-protective responses } \\
\text { Quality of life (the role of floods in people's lives) }\end{array}$ \\
\hline People & $\begin{array}{l}\text { Memories and flood experience } \\
\text { Socio-demographic characteristics } \\
\text { The role of social environment }\end{array}$ \\
\hline Geography of risk & $\begin{array}{l}\text { The role of spatial/geographical features } \\
\text { Relocation/moving out }\end{array}$ \\
\hline Feelings/emotions & The roles of particular emotions \\
\hline Theories, conceptual models & $\begin{array}{l}\text { Classifications of theories } \\
\text { Individual theories } \\
\text { Conceptual models }\end{array}$ \\
\hline
\end{tabular}




\section{Responsibility—Shared or Transferred to "Someone Else"?}

If there is a hallmark of the new FRM paradigm, then it is the idea of "shared responsibility." The idea means that the responsibility for flood protection, response, and post-flood recovery should be spread across a wider spectrum of agents, including not only those "traditionally" involved, such as various authorities (including governments), experts, agencies etc., but also agents such as individuals/individual households in general, or, especially, flood-prone areas' local residents and property owners [1,10,15-17].

Naturally, such a view of shared responsibility is a rather a generalized one: depending on the historical developments, cultural backgrounds, established (either past or present) practices of policy and decision-making, resources availability to agents involved and power transfers in-between of them, as well as environmental and many other factors, the related states of affairs and developmental pathways can take specific forms in particular countries and regions of the world. Thus, differences can be observed in this regard when considering the situation in, for example, Western Europe and in the countries of the so-called former Eastern Bloc [6,56,59-61], or when comparing the high-income countries with the low- or middle-income countries [28,29,52,62-69].

Taking into account the official proclamations of the idea of shared responsibility, it is dealt with, in a broader manner, in general frameworks such as the Sendai Framework for disaster risk reduction 2015-2030 [7,70], as well as, in a more specific manner, in documents such as the European Union Water Framework Directive (2000/60/EC) or the European Floods Directive (2007/60/EC); the latter two documents are expected to trigger the emergence of new governance frameworks in European Union Member States which will, except of other measures, encourage active involvement of various stakeholders [6,71-73], and place greater levels of responsibility for managing flood risk at the level of individual households [2].

The main assumption lying behind the idea of shared responsibility seems to be the one that responsibility creates an incentive for individuals and households to take action to mitigate their flood risk and prepare for recovery after a flood [74]. As the empirical evidence shows [30,49], people's beliefs about their own responsibility for protection represent important factors of why people do or do not act, or fail or succeed in protecting themselves from environmental hazards [8].

Yet, as already indicated (see Section 1), while the officials and authorities, insurers, or emergency and water management agencies expect local residents and property owners to take more responsibility for preparedness, response, and recovery, including the related activities and costs $[2,5,10,16,17,33,72]$, such an expectation does not meet with a desired appreciation and acceptance on the side of its addressees. On the contrary, though some examples of communities with stronger sense of responsibility were observed [37], only a minority of people generally (feel urge to) accept the idea that also they should take part in floods-relevant activities [8,30,45,75-77]. Rather, most people still tend to see FRM and related responsibility and activities as "someone else's job" [33] (p. 1593), and by that someone else they mostly mean central and local governments and authorities (see Section 3.1, Section 3.2, Section 3.3), but also insurance companies, researchers, planners, firefighters, and civil protection services, or even neighboring countries $[4,41,45-47,54,60,61,76-78]$. Somehow paradoxically, as rather insignificant seems to be whether the responsible entities' activities are perceived positively, or as being insufficient or inappropriate $[54,56,60,76]$.

\subsection{Governments and Authorities}

Consonant with the view of FRM as the end product of complex political and administrative interactions [13] is the common acknowledgement that governments and other authorities (hereafter the G\&A) still play a crucial role in it $[29,39,45,79,80]$. Yet this role seems to be a complicated one; Handmer [81], for instance, shows how local governments struggle with the task to borne and reconcile the policies and guidelines developed by (supra)national or state governments with other numerous issues competing for their attention (for example, the tensions between flood risk management and economic 
development). Moreover, the perceptions, intentions, or interests of the G\&A may differ a lot from those of lay public [82,83]; people often fail to differentiate individual levels of decision-making [60]; and they usually continue to perceive FRM as a state responsibility in general $[2,56]$, including not only the provision of protection and recovery measures, but also the imposition of particular restrictions, which, however, people (but also the G\&A themselves) in turn often tend to dispute or violate [6,44,45,47,77,84-87]. Furthermore, there are concerns about who is, actually, included in (or excluded from) decision-making processes, and about transfers of responsibility (to individuals, households, communities) without corresponding transfers of power or resources [18,21,71,73,80,88-91]. Hence, as frequently observed $[2,5,6,58,61,71,72]$, the G\&A, despite their official proclamations, often continue applying the "paternalist approach" [61] (p. 2562). Especially central governments still play the most important roles in FRM in the majority of countries: they shape regulatory frameworks, bear the ultimate responsibility for crisis management, and often provide a critical amount of money for post-disaster emergency relief and protection measures [72] (p. 95). Naturally, however, the situation is not the same everywhere; as, for example, Atreya et al. [28], Islam et al. [80] or Habib [92] point out, especially in the cases of middleor low-income countries, households/local communities, because of the state's limited resources and investments into the protection measures, often do not have many other choices than to bear the main burden of risk mitigation on their own, commonly relying on traditional/indigenous measures/survival strategies and local knowledge $[53,80]$.

\subsection{Public Protection Measures}

People in general do not tend to transfer the responsibility for flood protection only to someone, but also to something else; and this "something" usually means the public protection measures. There is a wide spectrum of such measures $[6,24,33,46,76,77,93]$; however, the technological/engineered, or the so-called structural measures (i.e., flood control structures such as dams or levees) have gained a special prominence in a variety of ways [2].

The (proclaimed) lowering preference of structural flood prevention options accompanying recent advancements in FRM is the result of recognition that despite fulfilling the convenient protection function, it is exactly this convenience that gives rise to a set of interrelated problems:

- First, these measures are, in a long-term, economically unbearable and unsustainable $[3,10,28,59,87]$;

- $\quad$ Second, these measures cannot provide absolute protection $[9,11,41,94]$, they can fail in providing protection in general $[11,41,65,69,95]$, and there is, therefore, always some residual risk associated with them $[2,62,96]$;

- Third, due to the structural measures' ability to lower the (perceived) frequency of floods, or to provide protection against minor floods, the construction and presence of such measures often leads to underestimation of the risk, (false) sense of security, (further) socio-economic development in the flood-prone areas, and through inhibiting the sense of one's own responsibility, to people's inaction regarding the private protection and mitigation measures $[2,3,9,15,31,56,75,76,96-98]$. As a result of this "levee effect" [2,95,97], a major flood may, in combination with insufficient protection and preparedness [11], increase the damages and losses [78].

Despite all of these issues, people in general still tend to rely and place their confidence upon the structural/technical measures $[2,4,33,59,62,75,76,78,97]$, favor them over the private or other public measures $[45,72,77]$, and call for their further enhancements $[45,61,77,87]$. In fact, these measures still play an important, if not decisive role in current FRM.

\subsection{Financial Issues and Funding of Protection and Recovery}

Financial aspect is one of the main constituents of the shared responsibility idea. Simply put, if the flood protection, or recovery are to be realized, someone has to pay for them. The issue of costs then naturally comes to the fore [99] with a request to spread these 
costs across a wider spectrum of agents [10,30]. It is less clear, however, who should belong to that spectrum (and who should not), and what kind and degree of "share" (in financial terms) the particular agents should take.

The willingness of individuals to get (more) involved in paying for protection and mitigation measures is variable. For example, it can be, depending on the specific circumstances, both positively and negatively influenced by previous experience with floods $[45,54,100]$. The issue is, however, a much more complicated one. Particular financial instruments playing important roles here are the ex-post compensation/relief mechanisms, ad hoc subsidies, or insurance. The combinations and ways of applying these instruments, which are provided both by public and private subjects (governments, insurance companies), or their partnerships (the so-called PPPs), tend to differ among individual countries, thus having differentiated impacts upon people's mitigation behavior [17,66,68,72,84,85,101-105].

For example, insurance, a prime risk transfer instrument, is assumed to be a sign of personal responsibility [77] and an incentive for additional risk reduction by households $[7,17,42,48,66]$. Moreover, insurance is also expected to reduce the financial uncertainty, since the large monetary loss from a flood is replaced with a smaller fixed costs in the form of the insurance premium [7].

Yet the costs, or the affordability of taking out insurance, as well as of adopting private mitigation measures, are often an issue $[7,16,17,35,42-44,47,54,84,104,106]$, not exceptionally associated with social (in)justice and inequality concerns $[17,28,85,89,91]$. For some households, insurance can be unavailable/inaccessible $[22,28,41,44,47,54,58]$, and such a situation, if overlapping with patterns of social inequality/deprivation or higher levels of vulnerability, can make the victims "trapped," fully dependent upon external support, and unable to adopt any private mitigation measures. Furthermore, if households depending on a limited budget pay for one of the options (insurance or measures), it may rule out the other one $[44,47,85]$, or it can lead to necessary tradeoffs between investments into mitigation measures/insurance and other components of general welfare $[91,106]$. There are also records of the obscure practices of insurance companies [22,30,41,45,47,54,85]; resulting reproaches, anger, or distrust then may lead to denial of insurance or other private activities.

Another mechanism assumed to be involved is the "charity hazard" [103], also called as the "crowding-out effect" [72] (p. 96); it explains that the existence of governmental relief programs, funded, for example, by tax money $[5,60,107]$, makes people passive regarding their own mitigation activities, including the (lowered) insurance demand [54]. In turn, then, the public sphere crowds-out the private one, and hence, it is not easy to decide about the "proper" extent of governmental responsibilities and assistance in financing flood protection and relief. Let alone that though most people still expect that such assistance will play a decisive role $[30,77]$, not all of them have to be at the same time enthusiastic about helping those endangered with their tax contributions [77]. This opens space for a profound, yet probably not clearly decidable contention: is it appropriate to place the main responsibility on the affected/endangered individuals, or rather rely on general solidarity and mutual support?

\section{Risk Perception-Does Awareness of the Threat Mean That People Will Act Accordingly?}

Perceptions of risk and awareness of the threat relate to the ways people subjectively assess the (potential) danger, and to the extent to which they possess and utilize the information about it [54] (p. 171). Risk perception is a key term and concept in recent research on risk prevention and mitigation [108-113], yet, somehow surprisingly, it lacks any clear and unambiguous definition, and thus is used quite loosely [114]. Therefore, the term awareness seems to be more specific and appropriate to express whether or what do people know about a given threat. Another related term/concept is the threat appraisal [2], which subsumes people's judgements regarding disaster's probability and its expected consequences $[1,36]$. 


\subsection{Threat Awareness and Information Availability}

Threat awareness is traditionally considered to be an essential component of flood preparedness $[2,7,31,32,39,97,115]$. It is assumed that if people know about the threat, they will act accordingly, i.e., they will engage in protection and mitigation activities. Correspondingly, the importance of information about the threat has been (and still is) stressed within relevant policies, and the so-called "information deficit model" [2] (p. 331) has been adopted to, through various "awareness campaigns" [116] (p. 217) and information channels such as lectures, personal agenda, mass media, maps, webpages, and other $[16,20,28,44,46,61,74,79,98,117]$, spread the risk-related information among the public and thus to foster common preparedness.

However, the assumptions lying behind these measures had proved to be wrong $[7,34,41,98,113]$. Research shows that information availability does not have to raise awareness, and both of them do not directly or necessarily predict expected behavior $[2,16,41,54,60,75,84,118,119]$. Rather, there is a typical contrast between the high proportion of people who state they are aware of the danger and the much lower proportion of those who make any personal preparations [32]. Moreover, people often simply lack interest in being informed and, correspondingly, underestimate or underutilize the available information [16,32,33,39,41,45,54,77]. Another issue can be the distrust toward those who supply the information [116].

\subsection{Denial and Cognitive Biases}

Another issue that needs to be considered is what does it actually mean "to be aware" of the threat. The perceived and actual risks are often misaligned $[32,47,78,120]$, and there is an inclination toward underestimation of the threat $[47,116]$. People tend to deny the possibility that the danger is real or acute, or they just believe that the disaster is less likely to happen (again) to them, personally [36,41,113,116,120-122].

Such simplifying mechanisms [120], called as the "ostrich effect" [116], "optimistic bias" [122], or "cognitive dissonance" [97], can be seen as non-protective responses to the threat: they do not prevent physical damages, but rather lessen the negative emotional consequences such as fear or anxiety [31] to insure day-to-day psychical functionality [97].

\subsection{Quality of Life}

It has been aptly pointed out by Burningham et al. [116] that much of the work on flood awareness focuses only on people's knowledge, understanding, and concerns about flooding, not on how these factors figure within broader evaluations of local life. Thus, though it might be assumed that floods, simply because of their potential to impose disorder on what contributes to well-being [10], are just "bad," and so people will do what they can against them, it turns out that the situation is not so straightforward. No doubt that floods have many negative impacts upon human lives, both direct and indirect $[45,51,68,87,97,123-125]$, and these impacts can be further aggravated by unfavorable living conditions; in this regard the life circumstances in the low- and middle-income countries seem to be of particular concern $[53,58,63-65,69,91,92,106]$.

Nevertheless, when it comes to the perceptions and attitudes, people, including those living in flood-prone areas, do not have to see floods in as significantly negative way as one might assume; for large (often prevailing) proportions of local populations, floods are associated with "moderate" or minimal impacts (or with no impacts at all) on their overall quality of life $[6,54,126,127]$. Some people might even consider floods to be an advantageous and unique feature of their place of residence [6]. In such cases, unsurprisingly, people's motivation to engage in mitigation activities does not have to be any strong.

\section{People-What Difference Does Who We Are Make?}

Communities exposed to hazards are not homogenous groups of people [79]; individuals and particular social formations differ regarding their characteristics, and these are, in turn, associated with the variations in risk judgments [111] and with certain patterns of disaster-relevant behaviors [121]. 


\subsection{Memories and Experience}

People may have very different historical backgrounds regarding their experience with floods [3] and such differences can have significant impact upon the ways individuals and communities perceive risk and prepare for a disaster $[1,11,31,59,79,83,121,128-131]$. However, the term experience is not unequivocally defined, interpreted, or applied $[36,113,114]$. It was suggested $[44,45]$ that the direct experience, compared to the indirect/vicarious one, is a key factor of change within endangered communities. Furthermore, people can be distinguished based on the fact, whether they were, or were not, personally affected by a disaster in the past (victims and non-victims). As some findings suggest, people with flood experience, and especially those affected/victims, compared to those without experience/unaffected, tend to perceive risk/threat or its potential consequences to be more severe, utilize (more frequently) more information resources about floods, or experience peculiar emotional responses to floods $[32,35,36,38,40,49,98,100,113,116,127]$; moreover, their cognitive biases may be reduced [122], and there is higher likelihood they will adopt the private mitigation measures $[22,35,49,54]$. Yet the findings are not uniform in all cases: it has been also found/suggested that the effect of experience is rather indirect [15], that it has no effect at all, or that it can even inhibit/reduce the private mitigation activities of households [16,32,40,41,47], including the taking out of insurance [22].

There are several (potential) reasons for these differing observations. For example, as already mentioned, conceptualizations of experience can differ in particular studies. Financial options for handling the floods vary among individual households or populations of particular countries or regions (see also Section 3.3). The character of the previously experienced flood(s) and the time aspect of the event need to be taken into account as well. Preparedness can increase with the magnitude and severity of past floods [22,113], yet failing to cope with the flood can also make people feel helpless, mistrustful toward mitigation measures, less willing to act, and more inclined toward the non-protective responses; at the same time the possibility that future floods may be smaller in magnitude and thus easier to manage than before may be overlooked [2]. On the other hand, the experience of relatively minor floods may lead to overestimation of current protection, a false sense of security, misjudgment of one's own ability to cope, and underestimation of the likelihood of a major event $[79,98,116]$.

The time aspect of flood experience subsumes two important features: the recentness and the frequency of floods. While recently experienced flooding may make people judge the probability and severity of a flood to be greater [15] and so engender higher awareness and interest in mitigation measures [41,100], experiences from a more distant past seem to have a rather minor influence on risk perception and mitigation behavior [1]. Bolstered by the (relative) infrequency and discrete character of floods, especially those major ones $[59,79,98]$, "the fading character of disaster experience" [98] (p. 1060) can result in a false sense of security, decreased risk awareness, and promotion of the optimistic bias [116]. On the other hand, it is not clear how fast extreme events are forgotten [35], and some findings suggest that memories of past experience do not have to necessarily "fade away" $[2,60]$. To sum up, the debate about the importance of floods' magnitude and time aspect in relation to experience and relevant behavior is still an ongoing one $[41,86,132,133]$.

\subsection{Socio-Demographic Characteristics}

The socio-demographic characteristics of people were found to be associated with the ways people perceive, prepare for, or respond to various risks [31,32,111,130], and with patterns of disaster damages, mortality, or variations in (social) vulnerability [14,51,95]. It is no surprise, then, that they are examined in almost every study on flood risk perception [49]; it was, however, also noted that some aspects of these characteristics, such as the demographic change, so far received rather little attention in FRM [134].

Because of the multitude of, often differing or contradictory, related findings, in this paper only a segment of them is presented and exemplified by means of three characteristics: age, sex/gender, and level of education. 


\subsubsection{Age}

From the viewpoint of relation between disasters and age, children and older people can be viewed as the two particularly vulnerable and burdened demographic groups $[14,37,45,46,51,53,87,115,124,135,136]$. However, the state of affairs is, once again, not so straightforward. For example, older people are, due to various factors more vulnerable than other age groups $[14,95,100,135,137]$, yet their lifetime experience(s) may also reduce their levels of hazards-related stress and worries $[97,127,135,137]$. Observations were made of positive correlation between age and risk perception [12,127], yet other findings are different or even quite opposite ones $[36,116,130,138]$. Considering the mitigation behavior, the presence of children in a household can promote the adoption of flood risk protection measures and strategies $[44,47,54]$. Younger people have been shown to prefer reactive strategies [32,54], while older people, due to factors such as physical [2] and financial [54] demands, or simply because they believe they have already "seen it all" [121] (p. 519), often tend to neglect any preparations. Conflicting findings were reported regarding the relationship between age and willingness to pay for mitigation measures [30,54].

\subsubsection{Sex/Gender}

Taking into account the sex/gender (hereafter only the term gender will be used), women are, compared to men, considered to be particularly vulnerable $[14,51,55]$ and affected by floods $[51,91,139]$. Yet women were also found to expect to suffer less flood damage [36], to prefer a longer periods of advanced warning [46], to report a higher negative impact of floods on their wellbeing [45], or to perceive a higher level of risk [1,11,12,38,127,130]. Women have been also characterized as more concerned about human health and safety [111], or more quickly reacting to a threat [121], especially if this concerns their family/household [97]. Men tend to demonstrate their manhood by "macho" behavior [121], so they might neglect the need for any preparations for a disaster [54]. Yet, the findings of particular studies regarding this topic often differ considerably [47,54]. Thus, some studies show that, in fact, men are more likely to have evacuation plans [32], and that more males in the household lead to more flood risk reduction measures being adopted [47].

\subsubsection{Education}

The educational level seems to be related with socioeconomic status, lifetime earnings, and ability to understand warnings and to access the recovery information [14]. People with more education can have better knowledge about floods [41], clearer understanding of related terms and facts [36], and tend to expect less government assistance and to endorse payments for property-level flood protection [30]. Such observations, however, are not uniform [54]. Moreover, higher levels of education do not necessarily mean raised flood awareness [54,97,140], and can be even associated with lower flood risk perception [127] or lower perceived flood probability and expectations to suffer less flood damage [36]. Nevertheless, higher educational levels were found to be associated with higher levels of personal responsibility, higher sense of capability to employ mitigation behaviors, and higher likelihood to adopt private mitigation measures $[16,30,54,57,140]$.

\subsubsection{Caveats and Limitations}

The findings presented here are only a fraction, though exemplary and telling one, of the whole amount of pertinent information gathered within a host of relevant studies. The particular findings often differ, probably due to factors such as differing methods of data acquisition and analysis, or due to differences regarding situations in individual communities or places [38]. Therefore, it is difficult, or even questionable, to establish any general patterns. Furthermore, the role of socio-demographic characteristics in flood risk research is not unquestionable as well. Some studies see such characteristics as rather poor [1,22] or ambiguous [31] predictors of floods-related behavior, or "only" as 
mediators or amplifiers of the main connections between experience, perception, and preparedness [98].

\subsection{Social Environment}

The role assigned to the social environment (social groups, social relationships) in affecting the floods-related behaviors is strongly dependent on a particular study's theoretical and methodological background. Some viewpoints can stress the influence of social position (such as class) or socio-political organization upon the vulnerability $[95,124]$, or the relationship between flood risk exposure and patterns of poverty, social inequality and environmental injustice $[91,135,136,141,142]$. Risk responses can be viewed as complex social processes [121], within which society takes cognize of the risks, facilitates precautionary behavior [113], and shapes the overall social [120] or individual [143] experience of risk and preparedness. The ways the local communities function $[28,37,79]$, the interpersonal linkages and networks $[7,32,80,138,144]$, mutual support and help $[4,40,44,45,136,138]$, the behavior and example of neighbors and friends [22,106,145], but also possible deterioration of relations associated with perceived unjust distribution of financial compensations, gossips and feelings of envy or reproach $[60,87]$ are all considered as significant for handling a disaster and preparations for another one. By recognizing the role of the strength and quality of social networks as substantially impacting the community's ability to cope and recover [37], the significance of trust in relation to the risk management's successful functioning has been highlighted [24,111]. As an analytical tool focusing upon the social relationships and bridging ties supporting the individual and community-based mitigation activities, the concept of social capital $[7,138,140]$ is often seen as "a key determinant of resilience and adaptive capacity" [10] (p. 39), enabling "the strengthening of memory about past natural disasters and the exchange of information about possible future risks and mitigation behavior" [61] (p. 2556). However, relevant research shows that the roles of social capital, social cohesion, or collective efficacy are not unambiguous: while some of their particular components can have a positive effect on general preparedness, the effect of some other (such as the overreliance on social support, linked with a false sense of safety) can, through reduction of risk perception, make households less likely to adopt mitigation measures [87,138,146,147].

\section{Location, Relocation and Place Attachment-Why to Live in The Place, When It Is at Risk?}

When it comes to floods, geography does matter. Spatial characteristics such as distance or elevation influence not only the actual risk, but also the way people perceive it $[36,44,53,69,90,108,125,138,144,148]$. Various settlement features relate to the character of social ties and community response to the threat $[4,61,73,97,149]$. Spatial relations and differences associated with various aspects of floods and floods-related behavior play a substantial role in most of the relevant studies $[11,12,14,46,60,76,77,79,95,116,130]$.

Another one issue closely related to location and spatial characteristics, and crucially important from the viewpoint of flood protection and mitigation behaviours, is the issue of the reasons why people live in flood-prone areas. The issue can be further divided into two aspects: why do people move into flood-prone areas, and why do they stay to live there, even after being hit by a disaster. The first aspect has been already, though rather implicitly, answered within previous sections of the paper: besides factors such as underestimation of the threat, transfer of responsibility to (and reliance upon) someone/something else, lack of awareness, unavailability or insufficient utilization of relevant information, infrequency of floods, or their low importance for the overall quality of life, the ever-changing and often place-specific interplay of many other personal, financial/economic, political, historical, or environmental factors influencing the decision-making processes throughout the whole spectrum of agents (from individual households to governments) needs to be taken into account here. In effect then, in general, the socio-economic development (including housing construction) in floodplains continues or even accelerates $[1,5,62,64,68,85,96,141,150]$. 
Focusing on the second aspect, i.e., the option of relocation or moving away from the endangered or already flooded area to a safer place, although such an option appears to be a reasonable adaptation strategy $[37,45,125]$ (potentially) reducing the risk of being flooded (again) to a zero [7], it seems to be applied rather exceptionally. In other words, once people (move to) live in the flood-prone areas, they usually stay there, even after being (repeatedly) hit by floods $[37,44,47,54,55,60,61,87,106]$. Factors already stated in relation to the first aspect are involved here as well, yet two groups of them seem to be of particular importance: the financial/economic factors, and the emotional ones. The prize of the land, together with a natural need of housing, can lure people to live in floodplains; the same factor, however, can turn out to be part of a "trap" of vicious circle of repeated floods and damages, insufficient refunds and issues of insurance (see Section 3.3), and impaired value of properties [45,97]. With the incapability to sell the properties for reasonable price [41], moving out of the area can become a task individually unattainable [61] and dependent upon external support such as governmental relocation programs $[7,151]$.

Other factors making people reluctant toward relocation (even in the cases of sufficient resources or external prompts) are emotional. These factors chiefly mean personal ties with a place, often called as a place attachment $[6,44,47]$, are often expressed through meanings and associations such as "family," "home," "place of birth," "childhood," "my land," "my way of life," "pride," "patriotism," etc. Humans tend to develop personal bonds to places [123], and such bonds influence risk denial [116] and flood preparedness [152]. Slovic [111] explains that the favorable associations affect the benefit-risk comparison by highlighting the positive aspect and lowering the importance of the negative one.

\section{Affects and Emotions-(How Much) Does It Matter What We Feel About Floods?}

There are various ways of defining and differentiating affects, emotions, and other related psychological states [153-155]. In the hazards, risks and risk management literature, however, these terms are usually used as modalities linked with the general notion of feelings. Taking into account their influence, it can be both positive and negative [40], direct and indirect [15] and, importantly, they can be seen as both causes and effects, i.e., simultaneously consequences of floods, and determinants of flood preparedness.

Recognizing the emotions as mechanisms directing fundamental psychological processes such as attention, memory, and information processing [111], feelings are still more emphasized as the missing link in risk perception research [38], or in the explanation of the disjoint between awareness and preparedness [2]. Within approaches such as fear appeal, risk-as-feelings hypothesis, affect heuristic, affect-as-information, social cognitive models, and others $[2,15,34,40,156]$, feelings appear as important determinants of whether (or whether not) and how people prepare for, and respond to, floods. By influencing the cognitive evaluation of a risk [1], or through the need to alleviate the negative affect [40], the positive effects of emotions can motivate people to take precautionary measures. The effect, however, can be also the opposite one, leading to demotivation [34].

The variegated effects of emotions can be demonstrated on examples of particular feelings, or rather groups of interrelated emotions and related psychological states and effects [37] commonly associated with floods. Some of them were already mentioned; for example, feelings associated with the place of residence can influence people's judgements regarding the risk, and the related decision of staying to live in areas that remain endangered. Emotions can also both positively and negatively affect the interpersonal/social relationships within endangered/affected communities [60], thus making them more or less resilient or vulnerable (see Section 5.3).

\subsection{Fear and Helplessness}

Enduring fear, worries, anxiety, or stress represent typical responses to disasters $[2,7,54,60]$. They seem to be much more prevalent among the affected people [35], they can be anytime recalled and invigorated by impulses and cues (for example rain) associated with the threat $[45,51,54]$, they bolster the catastrophic envisioning of future [45,60], and they can, yet 
not necessarily, lead to increased awareness, personal mitigation behavior, or willingness to pay for protection $[1,34,38,40,100,122]$.

On the contrary, feelings and states such as helplessness, powerlessness, or hopelessness weaken the motivation for one's own action and have a negative effect on protection behavior [1,51,61]. If fear or stress which usually motivate people to take precautionary measures, meet with learned helplessness, they are likely to result in the non-protective behavior [54,100]. In association with avoidance, denial, or postponement of realizing the protective measures, such maladaptive [22] or non-protective [1,2,31] responses mean that people "respond" to the disaster in a way that does not prevent or mitigate future losses, but rather leads to inactivity and increased vulnerability [22].

\subsection{Sorrow, Anger, Blaming, and Trust}

Resulting from damages and losses (unfortunately often including casualties), the sorrow of victims, of those people who have lost someone or something during a disaster, but also of those able to empathize with them or simply those hit by a vicarious experience often turns to anger and blaming. People usually see floods as "man-made" and so, after the disaster happens, they tend to look for someone to blame [41] (p. 266). This tendency is, once again, related to the issue of responsibility transfer (see Section 3), and with the unrealistic expectations of the public of the skills, capacities, and services that can be provided by the G\&A or other organizations [33]. These can be then blamed for insufficient reduction of the risk, escalation of flood losses and for (not) having issued building permits in flood-prone areas $[45,54,77]$, for letting people to stay unaware of, and lacking knowledge about, the danger [116], or for an inadequate help [46]. Moreover, the tendency to blame the G\&A seems to rise in compliance with the damages [60]. Blaming can also concern the public protection measures for their ineffectiveness during disaster events [61].

Yet, though often blaming someone or something for not doing things right, most people, rather than accepting their own share of responsibility for mitigation activities, still tend to rely on that someone or something else, whoever or whatever it is. Thus, somehow paradoxically, blaming goes hand in hand with trust, which, as stated by Wachinger et al. [98] (p. 1053), "is employed by individuals to manage personal risk through externalized faith." Naturally, trust needs to be considered in relation to its various forms, degrees, contexts, and effects. Trust-or lack of it-in authorities and experts, in other members of the community, in particular measures, in oneself/one's own capabilities to handle a threat, has a substantial impact on risk perception or (motivation to) protective and mitigation behavior $[5,15,16,22,34,71,80,90,98,104,147]$. Such an impact can be, however, both motivational/supportive (in terms of an individual's engagement in mitigation activities), or demotivating: in endangered communities, for example, trust represents a social relationships skill needed to sufficiently appraise the flood-related information and perform effective risk communication and joint action $[24,111,116]$; on the other hand, excessive trust can be linked with overreliance upon the help and protective abilities of someone/something else (government, local community, public measures) and with inhibitory effect on risk perception or private mitigation behaviors $[15,127,138,146,147]$.

\section{Theories and Concepts}

As presented throughout previous sections of this paper, there is a gamut of factors associated with the floods-relevant behaviors of various agents. Moreover, there is a widespread agreement of the fact that these factors are mutually intertwined within a kind of complex interplay $[2,7,12,13,15,32,37,38,79,98,120]$. However, it is much less clear (or agreed upon) how this interplay, in fact, works, i.e., how the respective bits and pieces interact with each other, what is the nature of their (causal) connections, or what kinds of outcomes they produce. 
8.1. Classifications of Approaches-What Kinds of Theories Do We Have at Hand to Explain Risk Perceptions and Floods-Related Behaviors?

There are a number of theories, concepts or (social-cognitive), models currently applied to help researchers to explore, examine, and explain (various aspects of) floods-relevant behaviors. The existence of such a range of possible approaches, however, also points to the fact that so far none of them was, and still is, able to offer fully comprehensive and reliable explanations of what has been observed, or even predictions of what will happen next $[7,15,16,43,47,157,158]$. In this regard, proposals for linking/combining various theories and application of overarching concepts such as human well-being have been made recently [7].

To make things more comprehensible, several more or less differing/overlapping overviews and classifications of diverse theoretical and methodological viewpoints and approaches have been recently worked out in pertinent studies. In this paper, some of those classifications are first presented in brief, and examples of particular theories and concepts are discussed afterwards.

With focus on risk perception, for example, the so-called psychometric paradigm associated with quantifications of individuals' risk perceptions and attitudes through survey questionnaires has been distinguished from a line of research designated as the heuristics, this one aiming attention at the rules of thumb used by people to simplify complex problems and to make decisions without using all of their cognitive capacities [49]. In another study, Birkholz et al. [9] (pp. 15-17), based on consideration of the recent developments in social sciences, identified two broad paradigms of approaches to risk perception: (a) the rationalist view, emphasizing individual cognitive processes and judgements within a "rational" decision-making process around the need to adopt protective behaviors, and including the "revealed preferences and psychometric paradigm" approaches and concepts of "Prospect Theory-heuristics and judgements"; and (b) the constructivist paradigm, preferring seeing risk, individual's judgements, and decision-making processes and behavioral options as being shaped rather by the social relationships and influences-the "social construction of risk" approaches and the "cultural theory of risk" are applied in the pertinent research.

Other classifications focus on approaches dealing with mitigation behavior and (establishing/portraying links between) a range of factors affecting it. Thus, for example, Kellens et al. [49] mention three basic approaches: the "expectancy valence theories" (see Section 8.2. for a more thorough discussion regarding some of them, for example the Protection Motivation Theory), the "contingent valuation methods" (economical approach to elicit people's preferences for public goods, such as environmental quality or flood protection), and the qualitative approaches. Another comprehensive overview has been offered by Weinstein [113], who summarizes the respective approaches under few main headings:

- Based on the awareness of preventive measures (and their availability, costs and perceived effectiveness), and perceived vulnerability to, and severity of, the threat, the "decision-making perspective" sees the need for action to be decided by weighing the magnitude of the threat against the costs and benefits associated with the available precautions;

- The approaches associated with "cognitive limitations and (other) issues" emphasize that though people's actions reflect their beliefs about risks and benefits, the beliefbehavior correspondence is, due to unmotivated errors in people's apprehension of information and various cognitive factors, far from perfect;

- The "fear as a direct or indirect motivator" perspective takes the position that reduction in fear (rather than avoidance of harm) is the goal of preventive behavior;

- Due to the "unrealistic optimism" perspective people tend to believe that they are not vulnerable or that they are less vulnerable than others around them, and such a bias inhibits preventive action; 
- Finally, the "social influence perspective" accentuates the social pressure (e.g., through praise or censure) upon victims to take precautions in order to avoid recurrences.

\subsection{Instantiating the Theoretical Underpinnings-What Do Some of The Particular Theories Say?}

Several examples can be stated to instantiate some of the theoretical views of riskrelated behavior, factors influencing it, and links between these factors. The theory of social amplification of risk [120] deals with the mechanism through which the social structures and processes of risk experience result in the repercussions on individual and group perceptions, and afterwards affect the community, society, and economy. The role of information about a threat and ways of its transmission and processing are emphasized: the nature and magnitude of risk are essentially determined by the information system and characteristics of public (social or individual) response. Risk events interact with psychological, social, and cultural processes and influence (intensify or attenuate) risk perceptions and related behavior. These in turn shape the social experience of risk and generate secondary effects increasing or decreasing the physical risk itself. Another stage of amplification may then occur to produce third-order impacts.

Another view is offered by the social cognitive model of disaster preparedness elaborated by Paton [34]: the model describes a developmental process that commences with factors that motivate people to prepare, progresses through the formation of intentions, and culminates in decisions to prepare. The interlinked factors implicated at particular stages of the process are motivators or precursors (risk perception, anxiety / fear, critical awareness), intention formation variables (self-efficacy, outcome expectancy, response efficacy, problem focused coping), and linkages between intentions and preparedness (perceived responsibility, timing of hazard activity, sense of community, normative factors such as trust and empowerment).

Green [24] discusses the elements influencing the mitigation behavior in a slightly different way. First, there needs to be a signal to adopt the desirable behavior (own responsibility, own strategies to handle the flood) and an incentive (for example social pressure, charges, subsidies) sufficient to overcome the barriers to adopting it. If there are no such barriers and the problem resides in lack of knowledge as to the more appropriate behavior, the solution means finding effective ways of ensuring that the signal is received and understood as intended (e.g., communication, flood mapping, campaigns to raise awareness, warnings).

The model called as "hazard to action chain" [98] (p. 1054), specifically addresses the issue of the weak relationship between risk perception and personal action. Three (groups of) intervening variables are taken into account here: experience and motivation, trust and responsibility, and personal ability (economic and personal conditions). Furthermore, three reasons are identified of why individuals, though they understand the risk, do not act accordingly: (a) The perceived benefits of living close to the river outweigh the potential negative impacts; (b) the responsibility for action is transferred to someone else; (c) there is a lack of resources to affect the situation present.

The protective action decision model (PADM) has been developed and so far applied to examine the behavior pertinent to various environmental risks, such as earthquakes or hurricanes, but also floods [112,159,160]; extensions of the model have been tested as well [157]. According to the model, environmental cues, observations of other people, or information from various sources initiate the awareness of a threat which, in turn, serves as a motivation to search for an appropriate response. Important role play here the risk area residents' beliefs regarding the environmental hazard (for example its severity, immediacy, consequences etc.) and the particular protective actions (efficacy, requirements). These, together with an adjustment context, vary as a function of hazard experience, social environment and relationships, and socio-demographic characteristics [160].

A final mention within this section is devoted to the so-called protection motivation theory (PMT), which recently gained special attention and a widespread application in risk research [54], including the flood risk research [1,2,9,15,22,31,49,84,145,161,162]. PMT 
builds upon two main cognitive processes (and their combined effect) influencing a protection motivation and self-preservation behavior [9,22], namely threat appraisal and coping appraisal. Threat appraisal (see also Section 4 ) is composed of perceived probability of being exposed to a threat and perceived severity of the threat's consequences [31]. Coping appraisal has three subcomponents: perceived response efficacy, perceived self-efficacy, and perceived costs, which include monetary, time, and effort factors [31]. If both appraisals are high, people tend to adopt protective behaviors (for example, they take up some private mitigation measures), while when the threat appraisal is high, but the coping appraisal is low, non-protective responses (see Section 4.2) are likely to follow. The basic model is often extended/adjusted through the incorporation of additional factors such as trust, responsibility, temporal changes, emotions, prior experience, personal characteristics, or social support $[2,15,22,31,40,138,140,163]$.

\subsection{Vulnerability and Resilience - Can the "Conceptual Frameworks/Models" Be the Right Answer?}

The notions of risk perception and flood preparedness are often more or less explicitly subsumed into broader concepts, or conceptual frameworks, such as exposure, resistance, susceptibility, vulnerability, or resilience. Especially the concepts of resilience and vulnerability seem to gain a special prominence in disaster research and risk management $[10,14,24,39,126,164-168]$. Although there exists a multitude of these concepts' definitions and schools of thought $[3,24,95,165,167,168]$, some commonalities can be observed in-between of them: typically, influenced by the ecological point of view $[10,24,126,169]$, the approach is systemic $[24,170]$, i.e., focusing upon social-ecological $[169,171]$ or humanenvironment systems [128], and their structure, constituents, relations, characteristics, and development. Emphasized are the interrelatedness, the importance assigned to the ability of humans to learn and to adapt deliberately $[31,86,128]$, and to people's preparedness regarding the risk they live with, and their capability to cope with the disaster and to recuperate [3]. Thus, the proximity to hazard and local environmental characteristics (exposure) are taken into account together with the ability of population to protect itself from a threat (resistance) and to recover after a disaster (resilience); vulnerability (to environmental hazards) then means the potential for loss, involving a combination of factors that determine the degree to which a person's life or livelihood is put at risk by a particular event $[14,86,95]$. Hence, the main task of various agents (potentially or actually) involved in FRM is to systematically follow the interrelated goals of recognizing exposure, reducing vulnerability, and enhancing resistance and resilience.

Yet, there are some impediments to fulfilling such a task, including the ambiguities and unclearness regarding the concepts' definitions, ways of interpretation, measurement, causal links in between system components, importance of particular relations and assessment of results of applied measures. As, for example, the study of Cashman [10] (p. 40) shows, even though there may be qualitative evidence of an increase in resilience, it is difficult to assess the degree to which it has been (positively) affected by particular actions taken. Naturally, there are sets of indicators and measurement frameworks at hand $[164,167,172] ;$ yet, once again, they are diverse and lack a general acceptance. Though such issues can be then tempting for academic debate, they may also be too elusive or unduly intricate for the lay public, with questionable effects on the actual preparedness and mitigation behaviors.

\section{Overview of Findings and Suggestions for Future Flood Risk Research Agenda}

A number of findings and views resulting from the flood risk research's effort to deal with various issues and factors of human floods-related decision-making processes and behaviors were presented and discussed in this paper so far. This section addresses their brief summary, overview, and several implications and suggestions for future research agenda resulting from them (these suggestions do not mean that all the particular topics, methods or theories mentioned are currently completely absent in the flood risk research; 
they rather mean that, because of the reasons stated, more/further attention should be paid to them).

\subsection{Responsibility}

If accepted, personal responsibility can motivate agents to act accordingly. However, the related issues of responsibility sharing or transfers are associated with concerns about injustice, lacking/insufficient transfers of power, and uncertainty caused by competing needs, interests, and actual options/resources. Thus, while agents may feel responsible and obliged to engage in a desired manner, they also may lack adequate capacities so to do. As a result, the inability to cope with the risk effectively in a long term or the tendency to transfer the responsibility to "someone" or "something" else might prevail, which still seems to be the usual case.

To acquire a fuller image of these issues, the links between costs, particular agents' (for example, households') actual options, available resources (affordability), and subjective views, as well as any kind of external support (for example, relief programs) need to be scrutinized more thoroughly. The triangulation research methodology could be applied here: merging and relating data from several resources (for example, insurance companies, statistical reports, planning documents, surveys or interviews) can shed more light on issues such as whether in cases of particular communities or households the costs or unavailability of insurance represent actually crucial impediments to mitigation behaviors, or rather the customary reliance on governmental support or public protection measures plays the decisive role here. In this regard, comparisons of related findings from high-, middle-, and low-income countries could probably offer interesting insights as well.

Further attention also needs to be paid both to the proclaimed and actual transfers of power and their relations to agents' everyday concerns and struggles. Analysis of texts, including the discourse analysis or semiotic narrative analysis, can be applied to examine the contents and (potential) effects of planning/policy-making documents; media analysis, content analysis, or studies on (political) practices can offer novel/deeper insights into the (often obscured) floods-related decision-making processes and power relations; for understanding the local and community-based views and judgements in this regard, interviews with local stakeholders and focus group discussions seem to be especially beneficial (see Table 3).

\subsection{Risk Perception}

The role of risk perception, threat awareness, and information availability in promoting preparedness should be neither underestimated (to act, people simply have to know about the threat), nor overrated (even if people know about the threat, it does not mean that they will act accordingly). Complex relations with many other factors of floods-related behavior mean that awareness or information availability usually cannot steer the people's actions in the desired direction on their own. For example, even if someone is interested in being informed (which, for various reasons, is often not the case), the acquisition of relevant information does not inevitably lead to the adoption of mitigation measures (for example, because of the costs). From the viewpoint of both FRM and flood risk research, these and the multitude of other related links still call for better understanding. 
Table 3. Responsibility-overview of findings, implications, and suggestions for future flood risk research agenda.

\begin{tabular}{|c|c|c|c|c|c|}
\hline $\begin{array}{l}\text { Issues of Concern } \\
\text { /Factors of Behavior }{ }^{1}\end{array}$ & FRM-Assumptions and Expectations & FRM-Issues & Flood Risk Research—Recent Knowledge & $\begin{array}{l}\text { Implications and Suggestions for } \\
\text { Future Research, Research Gaps }\end{array}$ & $\begin{array}{l}\text { Methods and Other Research } \\
\text { Considerations }\end{array}$ \\
\hline $\begin{array}{ll}\text { - } & \text { Responsibility sharing } \\
\text { and transfers } & \mathbf{A}^{-} \\
\text {- } & \text { The role of the G\&A }{ }^{\mathbf{B}} \\
\text { - } & \text { The role of public } \\
\text { protection measures } & \text { C } \\
\text { - } \quad \text { Financial issues }^{\mathbf{D}}\end{array}$ & $\begin{array}{l}\text { - } \quad \text { Responsibility and costs should be } \\
\text { spread across a wider spectrum of } \\
\text { agents } \mathrm{A}, \mathrm{D} \\
\text { Agents are expected to accept their } \\
\text { share of responsibility A,B } \\
\text { - Lowering preference of structural } \\
\text { flood protection measures } \mathrm{A}, \mathrm{C}, \mathrm{D}\end{array}$ & $\begin{array}{l}\text { - Responsibility is not } \\
\text { accepted by those } \\
\text { expected so to do }{ }^{\mathrm{A}, \mathrm{B}, \mathrm{D}} \\
\text { Issues of implementation } \\
\text { (e.g., tensions between } \\
\text { differing needs, ways of } \\
\text { development, and } \\
\text { interests of various agents; } \\
\text { continuing preference of } \\
\text { structural measures; lack } \\
\text { of resources) } \mathbf{A}, \mathbf{B}, \mathbf{C}, \mathbf{D} \\
\text { Combinations of } \\
\text { particular financial } \\
\text { instruments vary across } \\
\text { time and space, having } \\
\text { differentiated impacts } \\
\text { upon people's mitigation } \\
\text { behavior } \mathrm{A,D}\end{array}$ & 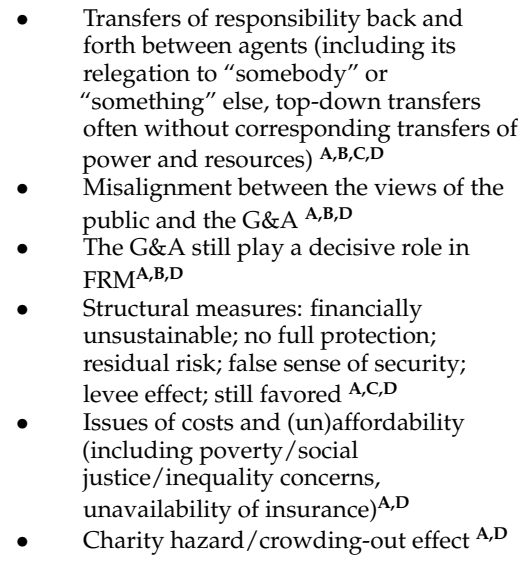 & 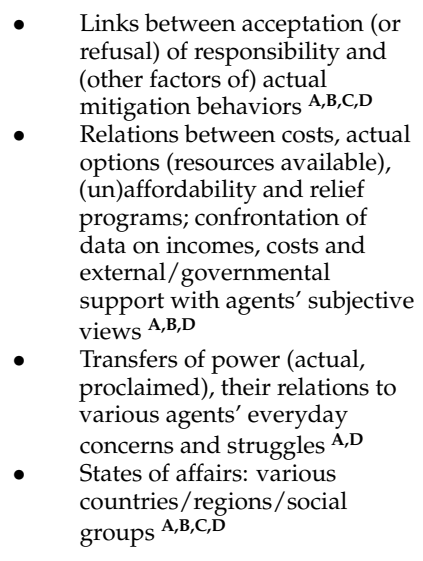 & 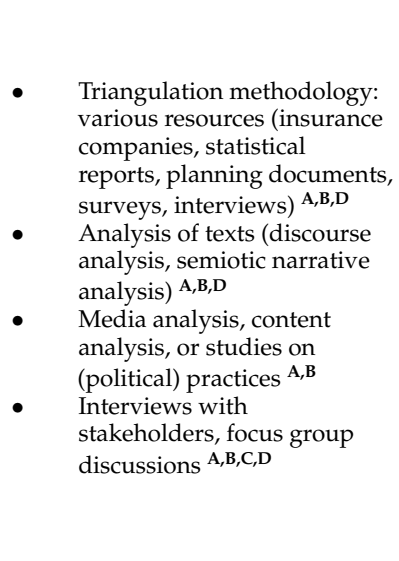 \\
\hline
\end{tabular}

${ }^{1}$ The main associations and links between the individual issues of concern and the information itemized in the remaining columns and bullets are indicated by the superscript letters. 
Phenomena that have been so far rather described than sufficiently explained are the underestimation of the flood threat, and the cognitive biases or the so-called non-protective responses (for example, avoidance, denial, wishful thinking, unfounded optimism, fatalism) in general. These are not only topics in need of further investigation (for example, to find out whether a transfer of responsibility to someone else is, under certain circumstances, rather a necessity or a non-protective response), but, potentially, also of reconsideration: though they can suppress the awareness and precautionary and mitigation behaviors, these "non-protective" responses also can, through their psychological regulatory functions of preventing excessive fear, worries, or stress, protect people's minds/mental health and thus, eventually, their general health. This issue thus also has a certain ethical dimension (for example, which of these functions should be preferred or suppressed under which circumstances), which should be considered both within relevant research and FRM, and which relates to potential changes to relevant terminology as well.

Taking into account their frequent use, it is somewhat surprising there is still ambiguity regarding the terminology and conceptualizations/definitions of such key terms as threat awareness or risk perception; clarifications are urgently needed here for the sake of refinements of research procedures, and for the meaningful interpretations and juxtapositions of particular studies' results.

Floods can play very diverse and differentiated roles in the everyday lives of particular individuals or social groups. A noticeable research gap still concerns more comprehensive examinations of these roles, including the issues of what floods actually mean to people, how these meanings (potentially) differ from those considered/utilized by researchers, and how do they affect people's choices and actions. Comparative analyses of the floods' impacts upon the lives of people in high and middle- to low-income countries could be useful for the assessments of, and recommendations for, political practices and FRM as well.

A variety of methods, including their integration/combination, could be of use to deal with the research tasks sketched. While, for example, text, media, or content analyses can be applied for inquiries on the policy information campaigns' contents, in-depth interviews might help us understand the actual effects of these campaigns' delivery. Interviews, the use of semantic differentials or open-ended questions (rather than those closed-ended ones with predetermined choices of responses) in questionnaires, or methods of ethnographic research could serve the task of (more thorough) understanding people's particular standpoints, (the reasons of) their actual responses to the threat they face, the meanings of floods in their lives, and the connotations they associate with floods and other floods-related issues (see Table 4).

\subsection{Socio-Demographic Characteristics}

Three main reasons probably stand behind the frequent use of socio-demographic variables such as age, gender, or education in flood risk research: the availability of pertinent data from statistical reports, certain research tradition in utilizing them to internally differentiate populations under study, and the intentions to uncover potential patterns of pertinent attitudes or actions. Such patterns, for example, show that age is usually associated with differences regarding flood experience; gender relates to different levels of vulnerability or meanings and importance attributed to particular risks and practices; and educational level is linked with personal preparedness and the amount and quality of information people tend to obtain and utilize. Nevertheless, not only are these observations not completely affirmed, but the (often contradictory) findings of relevant studies also show that many other links between characteristics of individuals and other factors of their risk-related behaviors are indeed present, yet not clear or generally valid. This suggests that, first, the socio-demographic characteristics can be no way taken as standalone determinants or direct predictors of particular actions, and, second, that the research on (the character of) their relations with other factors involved is further needed (see Table 5). 
Table 4. Risk perception-overview of findings, implications, and suggestions for future flood risk research agenda.

\begin{tabular}{|c|c|c|c|c|c|}
\hline $\begin{array}{l}\text { Issues of Concern } \\
\text { /Factors of Behavior }{ }^{1}\end{array}$ & FRM-Assumptions and Expectations & FRM-Issues & Flood Risk Research—Recent Knowledge & $\begin{array}{l}\text { Implications and Suggestions for } \\
\text { Future Research, Research Gaps }\end{array}$ & $\begin{array}{c}\text { Methods and Other Research } \\
\text { Considerations }\end{array}$ \\
\hline $\begin{array}{ll}\text { - } & \text { Threat awareness }{ }^{\mathbf{A}} \\
\dot{-} & \text { Information availability } \\
\text { B } & \text { Cognitive biases }{ }^{\mathrm{C}} \\
\text { - } & \text { Quality of } \text { life }^{\mathbf{D}}\end{array}$ & $\begin{array}{l}\text { - Threat awareness and information } \\
\text { about floods promote preparedness } \mathbf{A}, \mathbf{B} \\
\text { - Cognitive biases can be solved through } \\
\text { information availability } \mathbf{B , C} \\
\text { - People will act since they perceive } \\
\text { floods as a harmful constituent of their } \\
\text { lives } \mathbf{D}\end{array}$ & $\begin{array}{l}\text { - Assumptions are not fully } \\
\text { met } \mathrm{A}, \mathrm{B}, \mathrm{C}, \mathrm{D} \\
\text { Awareness campaigns and } \\
\text { information availability } \\
\text { do not predict interest or } \\
\text { expected behavior, } \\
\text { cognitive biases are still } \\
\text { present } \mathrm{A}, \mathrm{B}, \mathrm{C} \\
\text { Floods do not have to be } \\
\text { necessarily such an } \\
\text { important constituent of } \\
\text { people's lives to make } \\
\text { them act }{ }^{\mathrm{D}}\end{array}$ & $\begin{array}{l}\text { Threat awareness does not necessarily } \\
\text { predict behavior, other factors are } \\
\text { involved } \\
\text { Information availability does not raise } \\
\text { awareness, nor does it predict } \\
\text { behavior } \mathbf{A}, \mathbf{B} \\
\text { Information is often underestimated, } \\
\text { underutilized }{ }^{\mathbf{B}} \\
\text { People tend to underestimate the } \\
\text { threat, deny the possibility that the } \\
\text { danger is real or acute, believe that the } \\
\text { disaster is less likely to happen (again) } \\
\text { to them } \mathbf{A}, \mathbf{C} \\
\text { Floods play variegated and changing } \\
\text { roles in the lives of particular people } \\
\text { or social groups, the importance of } \\
\text { other factors can prevail, relations } \\
\text { between overall quality of life and } \\
\text { floods are of particular concern } \\
\text { regarding the middle- and } \\
\text { low-income countries } \mathbf{D}\end{array}$ & 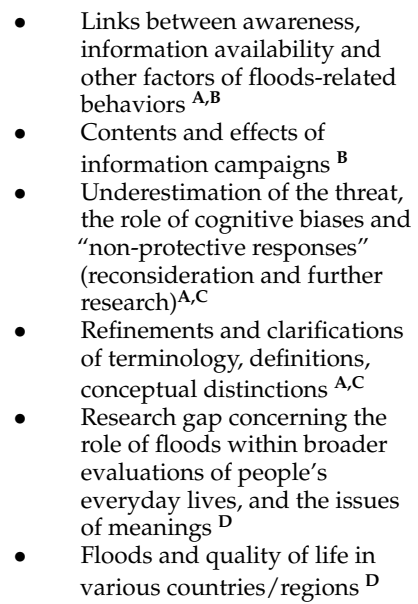 & 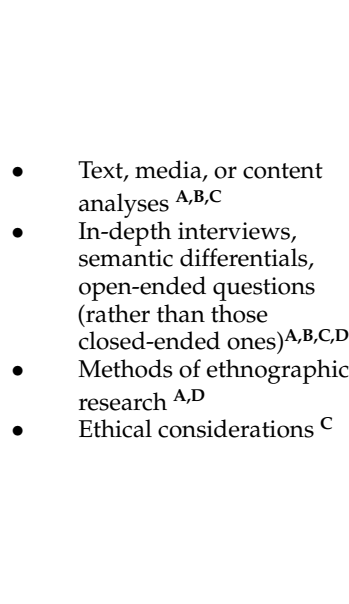 \\
\hline
\end{tabular}

${ }^{1}$ The main associations and links between the individual issues of concern and the information itemized in the remaining columns and bullets are indicated by the superscript letters. 
Table 5. People and floods-overview of findings, implications, and suggestions for future flood risk research agenda.

Issues of Concern/Factors of Behavior ${ }^{1}$

FRM-Assumptions and Expectations

FRM-Issues

Flood Risk Research-Recent
Knowledge

- $\quad$ Associations observe

age-experience;

gender-vulnerability,

- There are some

relevant associations

yet they are not

enough to be utilized

unambiguously $\mathbf{A}, \mathbf{B}, \mathbf{C}$

- Characteristics of people (including age, gender, education, flood

The role of the socio-demographic characteristics ${ }^{\mathbf{A}}$

The role of social environment $C$

experience) and social environment

predict floods-related behaviors $\mathrm{A}, \mathrm{B}, \mathrm{C}$

- Relevant information about these characteristics can be used to
promote preparedness $A, B, C$

- $\quad$ Flood experience does not necessarily predict

- Issues of

implementation (e.g. trust needs to be

supported, yet too

much reliance upon

each other can weaken

preparedness) ${ }^{C}$ particular risks and behavior

education-preparedness, the

amount and quality of information

utilized A

- Particular links are, however, not

clear-cut, other factors are

involved $\mathrm{A}, \mathrm{B}$

- There are different kinds of "flood

experience", they are associated

with various attitudes and

clear-cut, evidence is

- Social environment affects the

ways people deal with floods and

vice versa C

- The nature of social relationships can both support and weaken preparedness ${ }^{\mathrm{C}}$

- Views and findings can differ considerably due to differing
theoretical assumptions $\mathrm{C}$

\begin{tabular}{ccc} 
& $\begin{array}{c}\text { Implications and Suggestions for } \\
\text { Future Research, Research Gaps }\end{array}$ & \multicolumn{1}{c}{$\begin{array}{c}\text { Methods and Other Research } \\
\text { Considerations }\end{array}$} \\
\hline - $\quad$ Most of the relevant links are \\
still a matter of dispute
\end{tabular}

${ }^{1}$ The main associations and links between the individual issues of concern and the information itemized in the remaining columns and bullets are indicated by the superscript letters. 
The multitude of observed correlations between these and other variables/factors also suggest a methodological challenge for future flood risk research, namely the wider application of the multivariate analysis methods such as factor analysis, principal components analysis, cluster and discriminant analysis, the structural equation modelling (including the path analysis), and other. Drawing on various sources of data (for example, statistical reports, questionnaire surveys), and merging these data together, these methods can serve a few main goals, including identification of groups of strongly correlated variables or (dis)similar observations/cases, seeking for latent variables/dimensions of data, recognizing the redundant variables, and classifying the variables in terms of their explanatory power (and thus also potentially saving researchers' time, effort, and resources).

\subsection{Flood Experience}

There is a widespread accord within the research community that (flood) experience affects people's views of the risk/threat and what they (intend to) do about it; a direct experience and, especially, being one of the victims of/affected by flood through a personal loss or damage to private property is particularly important in this sense. However, the findings regarding particular effects of experience upon behavior are not uniform, and sometimes even contradictory. Thus, for example, while the factor in general is expected to encourage one's own mitigation actions, depending on the other circumstances and individual's options this does not have to be always the case. Once again, several other factors (such as actual or perceived costs, one's own abilities to mitigate the threat effectively and other) are involved here, yet the links between them and experience are still a matter of ongoing debate (see Table 5).

Out of the many pertinent directions of further research, two seem to be especially promising: the one focused on effects of the character of the very floods themselves, including their magnitude (for example, how major or minor floods affect experience and behavior), and the other one dealing with the time aspect of floods (for example, the relationships between experience/memories and the recency, duration, and frequency of floods, the ways the effect of flood experience changes over time, or simply how long the effect of experience lasts at all). Mixed approaches could be essentially beneficial for dealing with such research tasks, relating data from hydrological/climatological measurements, historical records, and archival research with observations of people's views and memories (examined through interviews, testimonies and oral histories), including their material aspect (memorials, visual clues such as markings of the floods' peaking levels on local houses).

The nature and meaning(s) of the experience itself seem to be another key area to be dealt with more thoroughly in the future. Experience is often applied as a generic/ undifferentiated term, and this can, because of the misapprehensions on the researcher(s)researcher(s) and researcher(s) - research participant(s) axes, cause vague or misleading inputs for research and interpretation of its findings. A set of semantic, conceptual, and terminological refinements and clarifications is needed here; drawing on methods such as interviews or open-ended questions, related with the issue is also an increased research interest in individual and social meanings of flood experience (for example, to address the issue of what does it actually mean "to be hit by a flood" for people living in flood-prone areas, and how the differing meanings affect their intentions and actions).

\subsection{Social Environment}

There is a consensus that (the character of) social environment affects flood preparedness, and that (the course and aftermath of) floods, in a way or another, affect the social environment. However, this seems to be where the limits of the consensus are, and where the differing or conflicting views and findings begin. The reviewed studies show, for example, that factors such trust and mutual support amongst community members can both increase and decrease preparedness; and in the aftermath of floods local/community 
relationships can both improve or get worse, and these effects are of questionable temporal duration and variability.

The role of the social environment is so far less than the partially explored field of flood risk research. Taking into account the differing levels (from local to global) upon which the "society" is regularly studied, as well as the complexity of networks involved, the spectrum of research goals, focuses and methods is an enormous one. For example, since the private precautionary and mitigation measures are adopted by residents of the flood-prone areas, the local level of investigation might seem to be of prime significance for research efforts. In such cases, the community-based approaches and case studies, the techniques of ethnographic research, the participant or non-participant observations, participant action research, focus groups interviewing or conversation analysis are greatly beneficial for acquiring data and understanding the particular social settings, (power) relations, and the ways these operate and function. Yet the local level of inquiry and action is also inevitably interrelated with the other (regional, national) ones through financial flows, resources transfers, political/decision-making regimes and processes, information campaigns, and a multitude of other links. Relating the local or regional findings to the processes and changes taking place worldwide can help us understand and interpret them in much wider frameworks and in relation to global issues (for example, the one of climate change); this intercommunication of findings has, moreover, a two-way supportive character.

The differing, theory-based, roles assigned to individuals and social relationships/ bonds/norms/structures are often the decisive factors standing behind differences regarding particular studies' concepts, data, methods, or findings. Yet, although there is apparently a number of various pertinent theoretical views already applied, a plethora of (other) social or social-psychological theories and approaches is still not utilized in studying floods-related perceptions and behaviors. Theoretical underpinnings thus represent another social environment-related challenge for flood risk research, associated also with the issue of proper conceptual distinctions (currently, for example, the concept of social capital seems to be applied often in a too general way).

Last, but not the least, the ethical considerations are in place here as well, for example in relation to judging and influencing the character of the social relationships (see Table 5).

\subsection{Geography of Risk}

A range of spatial and other geographical features of places or regions are associated not only with the actual and perceived flood risk, but also with the reasons why people live in the flood-prone areas at all; factors of why to live in endangered territories can, and this is rather the usual case, outweigh those of why not so to do. Moreover, people are, at least seemingly, mostly reluctant toward applying the adaptation strategy of moving out of the area, even if they have been already (possibly repeatedly) affected by floods. Among other factors, the financial impediments and emotional ties to the place seem to be of special importance in this regard.

The relationships between geographical characteristics of places (such as elevation, distance, population density, settlement's character and many other) and the risks they face still deserve further attention, if only because of the ongoing socio-economic development in flood-plains. There is a number of methods to be applied here, including the methodological developments based on their combination: such is the case of pinpointing data from surveys through positioning/localization technics (such procedures may be also ethically disputable), superposition of maps portraying subjective views of the threat with those of its actual presence, or analyses of the so-called cognitive/mental maps of areas by means of the Geographical Information Systems or computer-modelling procedures based on Artificial Intelligence.

Dealing with the attitudes, intentions, or actions of the respondents/participants who stayed to live in the endangered areas, but not of those people who had (possibly) moved out of there, seems to be a relatively frequent methodological limitation of pertinent studies 
(the author of this review feels indebted to an anonymous reviewer for pointing this out to him). Yet, even though conducting such a study may be more demanding, paying attention to views and stories both of people who stayed, and of those who (for whatever reasons) moved out from the flood-prone areas can bring more thorough insights into the relevant motivations, intentions, and factors of their realization.

Indicators and spatial patterns of social inequalities, deprivation, or poverty should be observed closely in relation to the flood-prone areas and in relation to the issues of (financial) resources allocation and social justice. Of specific concerns are these issues within the middle- and low-income countries, often experiencing rapid, unbridled urbanization.

The emotional ties and local identities people develop in relation to particular places still deserve further attention from researchers; studying personal/life histories, diaries, memoirs, (auto)biographies, photographs, or oral histories/narrations can add a lot of beneficial knowledge here. Moreover, triangulation/mixed methods approaches can be used to relate such data to those associated with financial options/impediments and prompts (such as support provided through relocation programs). This way, a noticeable research gap concerning which of the factors involved (emotional, financial, or other ones) prevail under which circumstances (for example, after a major flood) in affecting pertinent decision-making processes and actual actions taken, can be addressed (see Table 6).

\subsection{Emotions}

Along with the other associated factors, floods, their character, and their consequences, influence the nature of pertinent emotional responses. The emotions, in return, affect people's intentions and actions, including those related to floods; these effects can be both straightforward and convoluted, and, in terms of preparedness, both motivating and demotivating. For example, fear of experiencing a loss can motivate people to adopt mitigation measures. Yet if such measures showed up to be insufficient during the previous flood (potentially leading to feelings of helplessness), resignation, fatalistic views, or blaming and transfer of responsibility to someone else may result.

Many other links between particular emotional states themselves and other factors of preparedness still call for more thorough understanding. For example, the role of trust is still indeed a puzzling one: it can, depending on the particular circumstances, both support and hamper one's own mitigation behavior; moreover, trust is often, though counterintuitively, concurrent with blaming of those to whom it has been put (for example, the government). Several methods can be applied by the flood risk research not only to scrutinize the issue of "balanced" or "right degree" of trust in-between particular agents, but also to further examine the roles of other floods-related emotions, such as anger or sorrow. Questionnaires, in-depth interviews, ethnographic research, and observations of gestures/bodily movements can be applied (with keeping in mind the inseparable ethical considerations of such a research, and respecting the dignity of human beings) to study not only what people say, but also what do they do/how do they act (for example, just during the flood). Media analysis can be used to explore, for example, in what ways media represent disasters or inform about them (including the speeches of politicians), and how are such representations emotionally experienced by their receivers; next to self-reports, measurements of physiological reactions can be applied in such cases as well (see Table 7).

\subsection{Theories and Conceptual Models}

There are currently a handful of theories used in the flood risk research to study the protective and mitigation behaviors; some of them stem from this very research itself, others were adopted from other fields of scientific concern, yet they have all in common the efforts to describe and explain the (causal) mechanisms between particular factors involved. The differences between the theories and models are associated mainly with the ways they portray the links between these factors, or with the differing importance placed upon particular links or (sets of) factors; furthermore, while some theories aim for understanding the phenomenon under investigation in a (relatively) comprehensive way, 
others focus on some of its aspects, components, or processes involved (for example, the financial issues).

Except of its findings' practical application in FRM, the theoretical developments currently represent probably the greatest challenge, but also opportunity, for further advancements in flood risk research. Such developments will, presumably, take place in two interrelated lines: the first one means the continuous adjustments and refinements of the theoretical underpinnings already applied; within the other one, this extant repertoire will be extended by theories so far not frequently utilized in flood risk research. Completely newly developed theoretical underpinnings can thus appear, or the ones developed elsewhere can be utilized for the sake of studying flood risk perceptions and related human behaviors/agency as well (for example, feminist theories, sociology of associations and material semiotics, contemporary hermeneutics and other).

Three aspects of the further theoretical developments are worth special attention. First, attempts to develop any "universal" theory of what and why people do, or do not do, regarding the (flood) risk are rather a questionable endeavor; and application of the "all-embracing" concepts (such as, for example, the concept of well-being/quality of life) for such a task is disputable as well: while they can serve a better understanding of the circumstances of people's lives, the ambiguity of these concepts' definitions, theoretical basis, or methodological procedures can bring even more confusion where they were expected to bring explanation, unity, and order. Second, all theories applied in flood risk research can add something important to the understanding of the issues of concern; yet the pertaining contributions need to be considered carefully, taking into account that particular theories build on specific starting points, assumptions, methodologies, or kinds of empirical observations, and that the view they offer is only one of the many. Third, the combination in the sense of merging the particular theories may sound as a challenging idea (for example, flood risk research can be seen as having a great potential for bridging the natural and social sciences). Yet, caution is in order here as well. Since their ontological, epistemological, but also axiological or ethical foundations often differ fundamentally, the particular theories do not have to be mutually compatible (see Table 8). 
Table 6. Geography of risk-overview of findings, implications, and suggestions for future flood risk research agenda.

\begin{tabular}{|c|c|c|c|c|c|}
\hline $\begin{array}{l}\text { Issues of Concern } \\
\text { /Factors of Behavior }{ }^{1}\end{array}$ & FRM-Assumptions and Expectations & FRM-Issues & Flood Risk Research—Recent Knowledge & $\begin{array}{l}\text { Implications and Suggestions for } \\
\text { Future Research, Research Gaps }\end{array}$ & $\begin{array}{l}\text { Methods and Other Research } \\
\text { Considerations }\end{array}$ \\
\hline $\begin{array}{ll}\text { - } & \text { The role of } \\
\text { geographical/spatial } \\
\text { characteristics } \\
\text { Socio-economic } \\
\text { development in } \\
\text { floodplains } \mathbf{B} \\
\text { - } \\
\text { Moving out/relocation C }\end{array}$ & $\begin{array}{l}\text { Spatial features affect flood risk } \\
\text { and this needs to be taken into } \\
\text { account in planning processes }{ }^{\mathrm{A}, \mathrm{B}} \\
\text { The less people will live in } \\
\text { flood-prone areas, the lower the } \\
\text { vulnerability / flood risk }{ }^{\mathrm{B}, \mathrm{C}}\end{array}$ & $\begin{array}{l}\text { Despite an increasing } \\
\text { flood risk, the } \\
\text { socio-economic } \\
\text { development in } \\
\text { flood-prone areas } \\
\text { continues or even } \\
\text { accelerates }{ }^{\mathrm{B}, \mathrm{C}}\end{array}$ & $\begin{array}{l}\text { - Geographical features and spatial } \\
\text { characteristics (e.g., elevation, } \\
\text { distance, population density), } \\
\text { relations and differences affect the } \\
\text { actual and perceived risk }{ }^{\mathrm{A}} \\
\text { Reasons of why to live in flood prone } \\
\text { areas often outweigh those of why not } \\
\text { so to do } \mathrm{A}, \mathrm{B}, \mathrm{C} \\
\text { People develop emotional ties with } \\
\text { places C } \\
\text { Mainly because of these ties and/or } \\
\text { financial constraints people usually } \\
\text { stay to live in flood-prone areas even } \\
\text { after being hit by a flood } \mathrm{C}^{\mathrm{C}}\end{array}$ & $\begin{array}{l}\text { - Links between geographical } \\
\text { features of places and the risk } \\
\text { they face } \\
\text { People who (for whatever } \\
\text { reasons) moved out from the } \\
\text { flood-prone areas } \mathrm{C} \\
\text { Indicators and spatial patterns of } \\
\text { poverty, social inequalities or } \\
\text { deprivation in relation to } \\
\text { flood-prone areas and issues of } \\
\text { (financial) resources allocation } \\
\text { and social justice; situation in } \\
\text { low-income countries A,B } \\
\text { Emotional ties (place attachment) } \\
\text { and local identities } \mathrm{C} \\
\text { Factors of relocation/moving out, } \\
\text { including financial impediments } \\
\text { and prompts (e.g., relocation } \\
\text { programs) C } \\
\text { (Changes of) the relative } \\
\text { importance of particular factors, } \\
\text { such as the financial and } \\
\text { emotional ones, in affecting } \\
\text { moving out-related intentions } \\
\text { and behaviors } \mathrm{C}\end{array}$ & 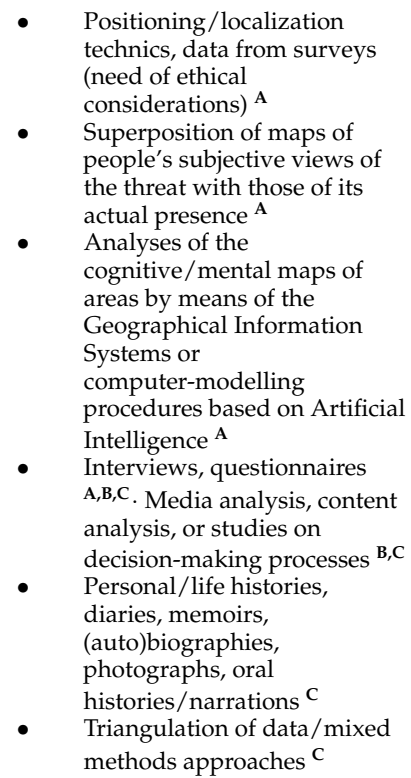 \\
\hline
\end{tabular}

${ }^{1}$ The main associations and links between the individual issues of concern and the information itemized in the remaining columns and bullets are indicated by the superscript letters. 
Table 7. Emotions/feelings-overview of findings, implications, and suggestions for future flood risk research agenda.

\begin{tabular}{|c|c|c|c|c|c|}
\hline $\begin{array}{l}\text { Issues of Concern } \\
\text { /Factors of Behavior }\end{array}$ & FRM-Assumptions and Expectations & FRM-Issues & Flood Risk Research—Recent Knowledge & $\begin{array}{l}\text { Implications and Suggestions for } \\
\text { Future Research, Research Gaps }\end{array}$ & $\begin{array}{l}\text { Methods and Other Research } \\
\text { Considerations }\end{array}$ \\
\hline - $\quad$ The role of emotions & $\begin{array}{l}\text { Emotions influence floods-related } \\
\text { decision-making processes and } \\
\text { behaviors } \\
\text { Relevant knowledge can be } \\
\text { useful for FRM policies }\end{array}$ & $\begin{array}{l}\text { Emotions are associated with } \\
\text { pertinent behaviors, yet the } \\
\text { character of these } \\
\text { associations is not a } \\
\text { straightforward one (e.g., } \\
\text { they can both motivate and } \\
\text { demotivate people to take } \\
\text { relevant actions) }\end{array}$ & $\begin{array}{l}\text { A set of emotions is typically } \\
\text { associated with floods (e.g., fear, } \\
\text { anger, sorrow, blame, hopelessness, } \\
\text { trust) } \\
\text { Fear can motivate people to adopt } \\
\text { mitigation measures and behaviors, } \\
\text { yet when it is associated with } \\
\text { helplessness, the effect can be the } \\
\text { opposite one } \\
\text { There are links (some even } \\
\text { paradoxical/counterintuitive) } \\
\text { between sorrow, anger, blaming and } \\
\text { trust, yet the nature of this links is still } \\
\text { unclear }\end{array}$ & $\begin{array}{l}\text { - Links between particular } \\
\text { emotional states (and other } \\
\text { factors of preparedness) } \\
\text { Paradoxical relations between } \\
\text { blaming and trust, and the } \\
\text { issue of "balanced" or "right } \\
\text { degree" of trust in-between } \\
\text { particular agents } \\
\text { Feelings-related perceptions, } \\
\text { meanings, physiological } \\
\text { responses } \\
\text { Refinements of terminology, } \\
\text { conceptual distinctions, and } \\
\text { theoretical basis }\end{array}$ & 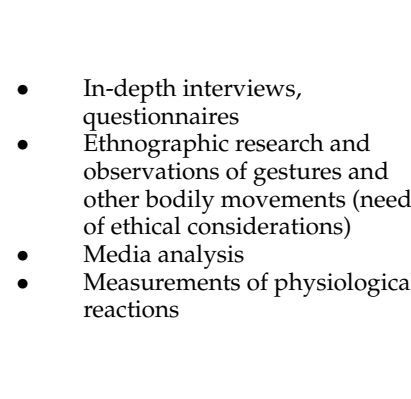 \\
\hline
\end{tabular}

Table 8. Theories, conceptual frameworks/models-overview of findings, implications, and suggestions for future flood risk research agenda.

\begin{tabular}{|c|c|c|c|c|c|}
\hline $\begin{array}{l}\text { Issues of Concern } \\
\text { /Factors of Behavior }\end{array}$ & FRM-Assumptions and Expectations & FRM-Issues & Flood Risk Research—Recent Knowledge & $\begin{array}{l}\text { Implications and Suggestions for } \\
\text { Future Research, Research Gaps }\end{array}$ & $\begin{array}{l}\text { Methods and Other Research } \\
\text { Considerations }\end{array}$ \\
\hline $\begin{array}{l}\text { - Theories, concepts, } \\
\text { models }\end{array}$ & $\begin{array}{l}\text { Floods-related behaviors can be } \\
\text { explained and thus also predicted } \\
\text { and influenced }\end{array}$ & $\begin{array}{l}\text { Explanatory and } \\
\text { predictive abilities of } \\
\text { extant theories are still } \\
\text { very limited, conceptual } \\
\text { models are variegated and } \\
\text { their application is } \\
\text { disputable }\end{array}$ & $\begin{array}{l}\text { A variety of more or less similar } \\
\text { theories and models is applied in } \\
\text { recent flood risk research, relevant } \\
\text { classifications are available } \\
\text { Some theories were developed within } \\
\text { flood risk research, some were } \\
\text { adopted from elsewhere } \\
\text { Differences relating to } \\
\text { comprehensiveness, focus on } \\
\text { particular (groups of) factors or links } \\
\text { between them }\end{array}$ & $\begin{array}{l}\text { - Adjustments and refinements } \\
\text { of the theories/models already } \\
\text { applied } \\
\text { "New" theories: either } \\
\text { completely new, or adopted } \\
\text { from elsewhere (e.g., } \\
\text { contemporary hermeneutics) }\end{array}$ & $\begin{array}{l}\text { - Further (critical/scrupulous) } \\
\text { considerations and caution } \\
\text { needed regarding: } \\
\text { (a) "universal" theory or the use } \\
\text { of "all-embracing" concepts } \\
\text { (e.g., quality of life); } \\
\text { (b) particular theories and their } \\
\text { particular starting points and } \\
\text { views; } \\
\text { (c) merging of theories }\end{array}$ \\
\hline
\end{tabular}




\section{Conclusions}

Recent FRM faces the issue of mismatched expectations: while the G\&A expect, at least officially, that people will engage more actively in floods-related tasks and processes such as flood preparedness and mitigation of the threat, most people remain reluctant, at least so it may seem, toward getting involved more actively in such an enterprise, and they still tend to expect that the G\&A (or, simply, someone, or something else) will take care of their safety and post-flood recovery. To offer insights to be able to better understand, explain, and potentially resolve this issue (and many other issues more or less related to it), flood risk research's effort aims at studying and understanding factors involved and the ways these are interconnected.

Based on the literature review, this paper focused on overviewing and synthesizing the findings and views resulting from such an endeavor. The main attention was paid to the private precautionary and mitigation activities and measures, and the reasons why these are (not) adopted by individuals and households. During the review process, factors of the issue currently considered to be of prime, or growing importance in flood risk research were identified, and these were discussed within the six key themes constituting the interpretation framework of the paper. Findings of this review point not only to the consensual views associated with flood risk perceptions and adoption of particular measures, but also to the conflicting findings and views as well. Moreover, results of this study indicate a considerable number of ambiguities, uncertainties, and research gaps, deserving to be addressed by future research agenda.

This study, naturally, has its limitations. The nature of the search strategy used and of the very review itself is a semi-systematic one. Thus, despite the author's best efforts to cover the issue under consideration comprehensively, not all studies on the subject of interest were included or studied thoroughly, and so not all pertinent findings and views could be taken into account. Since the information presented had to be necessarily generalized, particularities of relevant circumstances in individual countries or regions could not be discussed thoroughly. Since the study was conducted by a single author, there is a possibility of subjective bias regarding the study's particular stages and resulting information and interpretations. Regardless of these or any other limitations, the author believes that this paper will serve as a useful reference/departure point for those interested in (future) flood risk research and management.

Funding: This paper was elaborated in the scope of the project funded by the Czech Science Foundation "The nature and dynamics of local land use conflicts in a polyrational arena" (identification number 20-11782S).

Institutional Review Board Statement: Not applicable.

Informed Consent Statement: Not applicable.

Data Availability Statement: Data sharing is not applicable to this article.

Conflicts of Interest: The author declares no conflict of interest.

\section{References}

1. Bubeck, P.; Botzen, W.J.W.; Aerts, J.C.J.H. A Review of Risk Perceptions and Other Factors That Influence Flood Mitigation Behavior. Risk Anal. 2012, 32, 1481-1495. [CrossRef] [PubMed]

2. Fox-Rogers, L.; Devitt, C.; O’Neill, E.; Brereton, F.; Clinch, J.P. Is There Really “Nothing You Can Do"? Pathways to Enhanced Flood-Risk Preparedness. J. Hydrol. 2016, 543, 330-343. [CrossRef]

3. Messner, F.; Meyer, V. Flood damage, vulnerability and risk perception-Challenges for flood damage research. In Flood Risk Management: Hazards, Vulnerability and Mitigation Measures; Schanze, J., Zeman, E., Marsalek, J., Eds.; NATO Science Series; Springer: Dordrecht, The Netherlands, 2006; Volume 67, pp. 149-167.

4. Raška, P.; Warachowska, W.; Slavíková, L.; Aubrechtová, T. Expectations, Disappointments, and Individual Responses: Imbalances in Multilevel Flood Risk Governance Revealed by Public Survey. J. Flood Risk Manag. 2020, 13, e12615. [CrossRef]

5. Rauter, M.; Kaufmann, M.; Thaler, T.; Fuchs, S. Flood Risk Management in Austria: Analysing the Shift in Responsibility-Sharing between Public and Private Actors from a Public Stakeholder's Perspective. Land Use Policy 2020, 99, 105017. [CrossRef] 
6. Vávra, J.; Lapka, M.; Cudlínová, E.; Dvořáková-Líšková, Z. Local Perception of Floods in the Czech Republic and Recent Changes in State Flood Management Strategies. J. Flood Risk Manag. 2017, 10, 238-252. [CrossRef]

7. Kuhlicke, C.; Seebauer, S.; Hudson, P.; Begg, C.; Bubeck, P.; Dittmer, C.; Grothmann, T.; Heidenreich, A.; Kreibich, H.; Lorenz, D.F.; et al. The Behavioral Turn in Flood Risk Management, Its Assumptions and Potential Implications. Wires Water 2020, 7, e1418. [CrossRef]

8. Terpstra, T.; Gutteling, J.M. Households' Perceived Responsibilities in Flood Risk Management in The Netherlands. Int. J. Water Resour. Dev. 2008, 24, 555-565. [CrossRef]

9. Birkholz, S.; Muro, M.; Jeffrey, P.; Smith, H.M. Rethinking the Relationship between Flood Risk Perception and Flood Management. Sci. Total Environ. 2014, 478, 12-20. [CrossRef] [PubMed]

10. Cashman, A.C. Case Study of Institutional and Social Responses to Flooding: Reforming for Resilience? J. Flood Risk Manag. 2011, 4, 33-41. [CrossRef]

11. Ho, M.-C.; Shaw, D.; Lin, S.; Chiu, Y.-C. How Do Disaster Characteristics Influence Risk Perception? Risk Anal. 2008, 28 , 635-643. [CrossRef]

12. Kellens, W.; Zaalberg, R.; Neutens, T.; Vanneuville, W.; De Maeyer, P. An Analysis of the Public Perception of Flood Risk on the Belgian Coast. Risk Anal. 2011, 31, 1055-1068. [CrossRef] [PubMed]

13. Waugh, W.L., Jr.; Streib, G. Collaboration and Leadership for Effective Emergency Management. Public Adm. Rev. 2006, 66, 131-140. [CrossRef]

14. Cutter, S.L.; Boruff, B.J.; Shirley, W.L. Social Vulnerability to Environmental Hazards. Soc. Sci. Q. 2003, 84, 242-261. [CrossRef]

15. Bamberg, S.; Masson, T.; Brewitt, K.; Nemetschek, N. Threat, Coping and Flood Prevention-A Meta-Analysis. J. Environ. Psychol. 2017, 54, 116-126. [CrossRef]

16. Soane, E.; Schubert, I.; Challenor, P.; Lunn, R.; Narendran, S.; Pollard, S. Flood Perception and Mitigation: The Role of Severity, Agency, and Experience in the Purchase of Flood Protection, and the Communication of Flood Information. Environ. Plan. A 2010, 42, 3023-3038. [CrossRef]

17. Hudson, P. The Affordability of Flood Risk Property-Level Adaptation Measures. Risk Anal. 2020, 40, 1151-1167. [CrossRef]

18. Begg, C. Power, Responsibility and Justice: A Review of Local Stakeholder Participation in European Flood Risk Management. Local Environ. 2018, 23, 383-397. [CrossRef]

19. Godschalk, D.R.; Brody, S.; Burby, R. Public Participation in Natural Hazard Mitigation Policy Formation: Challenges for Comprehensive Planning. J. Environ. Plan. Manag. 2003, 46, 733-754. [CrossRef]

20. Kongmuang, C.; Tantanee, S.; Seejata, K. Urban Flood Hazard Map Usig GIS of Muang Sukhothai District, Thailand. Geogr. Tech. 2020, 15, 143-152. [CrossRef]

21. Thaler, T.; Seebauer, S. Bottom-up Citizen Initiatives in Natural Hazard Management: Why They Appear and What They Can Do? Environ. Sci. Policy 2019, 94, 101-111. [CrossRef]

22. Bubeck, P.; Botzen, W.J.W.; Kreibich, H.; Aerts, J.C.J.H. Detailed Insights into the Influence of Flood-Coping Appraisals on Mitigation Behaviour. Glob. Environ. Chang. 2013, 23, 1327-1338. [CrossRef]

23. Haidu, I.; Nicoară, M. GIS Procedure for the Identification of Existing Infrastructure in the Flooding Areas. Geogr. Tech. 2011, $14,30-44$.

24. Green, C. Towards Sustainable Flood Risk Management. Int. J. Disaster Risk Sci. 2010, 1, 33-43. [CrossRef]

25. Bark, R.H.; Acreman, M.C. Investigating Social Processes That Underpin Local Flood Risk Management Action. Environ. Sci. Policy 2020, 109, 95-102. [CrossRef]

26. Buchecker, M.; Ogasa, D.M.; Maidl, E. How Well Do the Wider Public Accept Integrated Flood Risk Management? An Empirical Study in Two Swiss Alpine Valleys. Environ. Sci. Policy 2016, 55, 309-317. [CrossRef]

27. Vinke-de Kruijf, J.; Kuks, S.M.M.; Augustijn, D.C.M. Governance in Support of Integrated Flood Risk Management? The Case of Romania. Environ. Dev. 2015, 16, 104-118. [CrossRef]

28. Atreya, A.; Czajkowski, J.; Botzen, W.; Bustamante, G.; Campbell, K.; Collier, B.; Ianni, F.; Kunreuther, H.; Michel-Kerjan, E.; Montgomery, M. Adoption of Flood Preparedness Actions: A Household Level Study in Rural Communities in Tabasco, Mexico. Int. J. Disaster Risk Reduct. 2017, 24, 428-438. [CrossRef]

29. Mercado, J.M.R.; Kawamura, A.; Amaguchi, H. Interrelationships of the Barriers to Integrated Flood Risk Management Adaptation in Metro Manila, Philippines. Int. J. Disaster Risk Reduct. 2020, 49, 101683. [CrossRef]

30. Henstra, D.; Thistlethwaite, J.; Brown, C.; Scott, D. Flood Risk Management and Shared Responsibility: Exploring Canadian Public Attitudes and Expectations. J. Flood Risk Manag. 2019, 12, e12346. [CrossRef]

31. Grothmann, T.; Reusswig, F. People at Risk of Flooding: Why Some Residents Take Precautionary Action While Others Do Not. Nat. Hazards 2006, 38, 101-120. [CrossRef]

32. Box, P.; Bird, D.; Haynes, K.; King, D. Shared Responsibility and Social Vulnerability in the 2011 Brisbane Flood. Nat. Hazards 2016, 81, 1549-1568. [CrossRef]

33. Box, P.; Thomalla, F.; Van den Honert, R. Flood Risk in Australia: Whose Responsibility Is It, Anyway? Water 2013, 5, $1580-1597$. [CrossRef]

34. Paton, D. Disaster Preparedness: A Social-cognitive Perspective. Disaster Prev. Manag. Int. J. 2003, 12, 210-216. [CrossRef]

35. Siegrist, M.; Gutscher, H. Natural Hazards and Motivation for Mitigation Behavior: People Cannot Predict the Affect Evoked by a Severe Flood. Risk Anal. 2008, 28, 771-778. [CrossRef] 
36. Botzen, W.J.W.; Aerts, J.C.J.H.; van den Bergh, J.C.J.M. Dependence of Flood Risk Perceptions on Socioeconomic and Objective Risk Factors. Water Resour. Res. 2009, 45. [CrossRef]

37. Keogh, D.U.; Apan, A.; Mushtaq, S.; King, D.; Thomas, M. Resilience, Vulnerability and Adaptive Capacity of an Inland Rural Town Prone to Flooding: A Climate Change Adaptation Case Study of Charleville, Queensland, Australia. Nat. Hazards 2011, 59, 699-723. [CrossRef]

38. Miceli, R.; Sotgiu, I.; Settanni, M. Disaster Preparedness and Perception of Flood Risk: A Study in an Alpine Valley in Italy. J. Environ. Psychol. 2008, 28, 164-173. [CrossRef]

39. Osti, R.; Nakasu, T. Lessons Learned from Southern and Eastern Asian Urban Floods: From a Local Perspective. J. Flood Risk Manag. 2016, 9, 22-35. [CrossRef]

40. Zaalberg, R.; Midden, C.; Meijnders, A.; McCalley, T. Prevention, Adaptation, and Threat Denial: Flooding Experiences in the Netherlands. Risk Anal. 2009, 29, 1759-1778. [CrossRef]

41. Lave, T.R.; Lave, L.B. Public Perception of the Risks of Floods: Implications for Communication. Risk Anal. 1991, 11, 255-267. [CrossRef]

42. Montgomery, M.; Kunreuther, H. Pricing Storm Surge Risks in Florida: Implications for Determining Flood Insurance Premiums and Evaluating Mitigation Measures. Risk Anal. 2018, 38, 2275-2299. [CrossRef] [PubMed]

43. Attems, M.-S.; Thaler, T.; Genovese, E.; Fuchs, S. Implementation of Property-Level Flood Risk Adaptation (PLFRA) Measures: Choices and Decisions. Wires Water 2020, 7, e1404. [CrossRef]

44. Bera, M.K.; Daněk, P. The Perception of Risk in the Flood-Prone Area: A Case Study from the Czech Municipality. Disaster Prev. Manag. 2018, 27, 2-14. [CrossRef]

45. Bird, D.; King, D.; Haynes, K.; Box, P.; Okada, T.; Nairn, K. Impact of the 2010-11 Floods and the Factors That Inhibit and Enable Household Adaptation Strategies; National Climate Change Adaptation Research Facility: Gold Coast, Australia, 2013.

46. Brilly, M.; Polic, M. Public Perception of Flood Risks, Flood Forecasting and Mitigation. Nat. Hazards Earth Syst. Sci. 2005, 5, 345-355. [CrossRef]

47. Duží, B.; Vikhrov, D.; Kelman, I.; Stojanov, R.; Juřička, D. Household Measures for River Flood Risk Reduction in the Czech Republic. J. Flood Risk Manag. 2017, 10, 253-266. [CrossRef]

48. Hudson, P.; Botzen, W.J.W.; Aerts, J.C.J.H. Flood Insurance Arrangements in the European Union for Future Flood Risk under Climate and Socioeconomic Change. Glob. Environ. Chang. 2019, 58, 101966. [CrossRef]

49. Kellens, W.; Terpstra, T.; De Maeyer, P. Perception and Communication of Flood Risks: A Systematic Review of Empirical Research. Risk Anal. 2013, 33, 24-49. [CrossRef]

50. Nojang, E.N.; Jensen, J. Conceptualizing Individual and Household Disaster Preparedness: The Perspective from Cameroon. Int. J. Disaster Risk Sci. 2020, 11, 333-346. [CrossRef]

51. Tapsell, S.; Penning-Rowsell, E.; Tunstall, S.M.; Wilson, T.L. Vulnerability to Flooding: Health and Social Dimensions. Philos. Trans. Ser. A Math. Phys. Eng. Sci. 2002, 360, 1511-1525. [CrossRef]

52. Biswas, S.; Hasan, M.A.; Islam, M.S. Stilt Housing Technology for Flood Disaster Reduction in the Rural Areas of Bangladesh. Int. J. Res. Civ. Eng. Archit. Des. 2015, 3, 1-6.

53. Dewan, T.H. Societal Impacts and Vulnerability to Floods in Bangladesh and Nepal. Weather Clim. Extrem. 2015, 7, 36-42. [CrossRef]

54. Andráško, I.; Klemešová, K.D.; Dolák, L.; Trojan, J.; Fiedor, D. “Surely It Will Come Again ... ”. Flood Threat Appraisal, Mitigation Strategies and Protection Motivation in Czech Communities Endangered by Floods. Morav. Geogr. Rep. 2020, 28, 170-186. [CrossRef]

55. Kamal, A.S.M.M.; Shamsudduha, M.; Ahmed, B.; Hassan, S.M.K.; Islam, S.; Kelman, I.; Fordham, M. Resilience to Flash Floods in Wetland Communities of Northeastern Bangladesh. Int. J. Disaster Risk Reduct. 2018, 31, 478-488. [CrossRef]

56. Vaishar, A.; Hlavinková, P.; Máčka, Z. Landscape, Settlement and Floods in the Hanušovice/Jindřichov Model Region (Northern Moravia). Morav. Geogr. Rep. 2000, 8, 30-44.

57. Osberghaus, D. The Effect of Flood Experience on Household Mitigation-Evidence from Longitudinal and Insurance Data. Glob. Environ. Chang. 2017, 43, 126-136. [CrossRef]

58. Luu, C.; Von Meding, J.; Kanjanabootra, S. Flood Risk Management Activities in Vietnam: A Study of Local Practice in Quang Nam Province. Int. J. Disaster Risk Reduct. 2018, 28, 776-787. [CrossRef]

59. Raška, P. Flood Risk Perception in Central-Eastern European Members States of the EU: A Review. Nat. Hazards 2015, 79, 2163-2179. [CrossRef]

60. Klemešová, K.D.; Andráško, I. Perception of Floods-towards More Effective Flood Management in the Czech Republic. Carpathian J. Earth Environ. Sci. 2015, 10, 199-208.

61. Działek, J.; Biernacki, W.; Bokwa, A. Challenges to Social Capacity Building in Flood-Affected Areas of Southern Poland. Nat. Hazards Earth Syst. Sci. 2013, 13, 2555-2566. [CrossRef]

62. Mohanty, M.P.; Mudgil, S.; Karmakar, S. Flood Management in India: A Focussed Review on the Current Status and Future Challenges. Int. J. Disaster Risk Reduct. 2020, 49, 101660. [CrossRef]

63. De Risi, R.; De Paola, F.; Turpie, J.; Kroeger, T. Life Cycle Cost and Return on Investment as Complementary Decision Variables for Urban Flood Risk Management in Developing Countries. Int. J. Disaster Risk Reduct. 2018, 28, 88-106. [CrossRef] 
64. Nkwunonwo, U.C.; Whitworth, M.; Baily, B. A Review of the Current Status of Flood Modelling for Urban Flood Risk Management in the Developing Countries. Sci. Afr. 2020, 7, e00269. [CrossRef]

65. Pisaniello, J.D.; Dam, T.T.; Tingey-Holyoak, J.L. International Small Dam Safety Assurance Policy Benchmarks to Avoid Dam Failure Flood Disasters in Developing Countries. J. Hydrol. 2015, 531, 1141-1153. [CrossRef]

66. Surminski, S.; Oramas-Dorta, D. Flood Insurance Schemes and Climate Adaptation in Developing Countries. Int. J. Disaster Risk Reduct. 2014, 7, 154-164. [CrossRef]

67. Bezada, M. Natural Hazards and Human-Induced Disasters Triggered by Intense and Episodic Tropical Rains in the Venezuelan Mountains. In Developments in Earth Surface Processes; Latrubesse, E.M., Ed.; Elsevier: Amsterdam, The Netherlands, 2009; Volume 13, pp. 115-129.

68. Sprissler, T. Flood Risk in Brazil. Prevention, Adaptation and Insurance; Swiss Reinsurance Company Ltd.: Zurich, Switzerland, 2011.

69. Shah, S.M.H.; Mustaffa, Z.; Teo, F.Y.; Imam, M.A.H.; Yusof, K.W.; Al-Qadami, E.H.H. A Review of the Flood Hazard and Risk Management in the South Asian Region, Particularly Pakistan. Sci. Afr. 2020, 10, e00651. [CrossRef]

70. Cox, R.S.; Hill, T.T.; Plush, T.; Heykoop, C.; Tremblay, C. More than a Checkbox: Engaging Youth in Disaster Risk Reduction and Resilience in Canada. Nat. Hazards 2019, 98, 213-227. [CrossRef]

71. Jager, W.N.; Challies, E.; Kochskämper, E.; Newig, J.; Benson, D.; Blackstock, K.; Collins, K.; Ernst, A.; Evers, M.; Feichtinger, J.; et al. Transforming European Water Governance? Participation and River Basin Management under the EU Water Framework Directive in 13 Member States. Water 2016, 8, 156. [CrossRef]

72. Slavikova, L. Effects of Government Flood Expenditures: The Problem of Crowding-Out. J. Flood Risk Manag. 2018, 11, 95-104. [CrossRef]

73. Slavíková, L.; Raška, P.; Kopáček, M. Mayors and "Their" Land: Revealing Approaches to Flood Risk Management in Small Municipalities. J. Flood Risk Manag. 2019, 12, e12474. [CrossRef]

74. Henstra, D.; Thistlethwaite, J. Flood Risk and Shared Responsibility in Canada: Operating on Flawed Assumptions? CIGI Policy Brief. 2017, No. 116, 1-6.

75. De Marchi, B.; Scolobig, A.; Delli Zotti, G.; Zotto, M. Risk Construction and Social Vulnerability in an Italian Alpine Region; ISIG: Gorizia, Italy, 2007.

76. Figueiredo, E.; Valente, S.; Coelho, C.; Pinho, L. Coping with Risk: Analysis on the Importance of Integrating Social Perceptions on Flood Risk into Management Mechanisms-the Case of the Municipality of Águeda, Portugal. J. Risk Res. 2009, 12, 581-602. [CrossRef]

77. Vari, A.; Linnerooth-Bayer, J.; Ferencz, Z. Stakeholder Views on Flood Risk Management in Hungary's Upper Tisza Basin. Risk Anal. 2003, 23, 585-600. [CrossRef] [PubMed]

78. McPherson, H.J.; Saarinen, T.F. Flood Plain Dwellers' Perception of the Flood Hazard in Tucson, Arizona. Ann. Reg. Sci. 1977, 11, 25-40. [CrossRef]

79. Burn, D.H. Perceptions of Flood Risk: A Case Study of the Red River Flood of 1997. Water Resour. Res. 1999, 35, 3451-3458. [CrossRef]

80. Islam, M.R.; Ingham, V.; Hicks, J.; Kelly, E. From Coping to Adaptation: Flooding and the Role of Local Knowledge in Bangladesh. Int. J. Disaster Risk Reduct. 2018, 28, 531-538. [CrossRef]

81. Handmer, J. Policy Design and Local Attributes for Flood Hazard Management. J. Contingencies Crisis Manag. 1996, 4, 189-197. [CrossRef]

82. Ceobanu, C.; Grozavu, A. Psychosocial Effects of the Floods. Perception and Attitudes. Carpathian J. Earth Environ. Sci. 2009, 4, 25-38.

83. Fuchs, S.; Karagiorgos, K.; Kitikidou, K.; Maris, F.; Paparrizos, S.; Thaler, T. Flood Risk Perception and Adaptation Capacity: A Contribution to the Socio-Hydrology Debate. Hydrol. Earth Syst. Sci. 2017, 21, 3183-3198. [CrossRef]

84. Schlef, K.E.; Kaboré, L.; Karambiri, H.; Yang, Y.C.E.; Brown, C.M. Relating Perceptions of Flood Risk and Coping Ability to Mitigation Behavior in West Africa: Case Study of Burkina Faso. Environ. Sci. Policy 2018, 89, 254-265. [CrossRef]

85. Surminski, S. Fit for Purpose and Fit for the Future? An Evaluation of the UK's New Flood Reinsurance Pool. Risk Manag. Insur. Rev. 2018, 21, 33-72. [CrossRef]

86. Aguilar-Barajas, I.; Sisto, N.P.; Ramirez, A.I.; Magaña-Rueda, V. Building Urban Resilience and Knowledge Co-Production in the Face of Weather Hazards: Flash Floods in the Monterrey Metropolitan Area (Mexico). Environ. Sci. Policy 2019, 99, 37-47. [CrossRef]

87. Vaishar, A.; Hlavinková, P.; Kirchner, K.; Lacina, J. Long-Term Impacts of the 1997 Floods in the Morava River Basin. Geografie 2000, 105, 141-154. [CrossRef]

88. Begg, C.; Callsen, I.; Kuhlicke, C.; Kelman, I. The Role of Local Stakeholder Participation in Flood Defence Decisions in the United Kingdom and Germany. J. Flood Risk Manag. 2018, 11, 180-190. [CrossRef]

89. Fothergill, A.; Peek, L.A. Poverty and Disasters in the United States: A Review of Recent Sociological Findings. Nat. Hazards 2004, 32, 89-110. [CrossRef]

90. Bustillos Ardaya, A.; Evers, M.; Ribbe, L. Participatory Approaches for Disaster Risk Governance? Exploring Participatory Mechanisms and Mapping to Close the Communication Gap between Population Living in Flood Risk Areas and Authorities in Nova Friburgo Municipality, RJ, Brazil. Land Use Policy 2019, 88, 104103. [CrossRef] 
91. Eakin, H.; Lerner, A.M.; Manuel-Navarrete, D.; Hernández Aguilar, B.; Martínez-Canedo, A.; Tellman, B.; Charli-Joseph, L.; Fernández Álvarez, R.; Bojórquez-Tapia, L. Adapting to Risk and Perpetuating Poverty: Household's Strategies for Managing Flood Risk and Water Scarcity in Mexico City. Environ. Sci. Policy 2016, 66, 324-333. [CrossRef]

92. Habib, H. Water Related Problems in Afghanistan. Int. J. Educ. Stud. 2014, 1, 137-144.

93. Gacko, I.; Muchová, Z.; Jurík, L'.; Šinka, K.; Fabian, L.; Petrovič, F. Decision Making Methods to Optimize New Dam Site Selections on the Nitra River. Water 2020, 12, 2042. [CrossRef]

94. Tran, D.D.; van Halsema, G.; Hellegers, P.J.G.J.; Ludwig, F.; Seijger, C. Stakeholders' Assessment of Dike-Protected and FloodBased Alternatives from a Sustainable Livelihood Perspective in An Giang Province, Mekong Delta, Vietnam. Agric. Water Manag. 2018, 206, 187-199. [CrossRef]

95. Burton, C.; Cutter, S. Levee Failures and Social Vulnerability in the Sacramento-San Joaquin Delta Area, California. Nat. Hazards Rev. 2008, 9, 136-149. [CrossRef]

96. Montz, B.; Tobin, G. From False Sense of Security to Residual Risk: Communicating the Need for New Floodplain Development Models. Geogr. Časopis 2008, 60, 3-14.

97. Armas, I.; Ionescu, R.; Posner, C.N. Flood Risk Perception along the Lower Danube River, Romania. Nat. Hazards 2015, 79, 1913-1931. [CrossRef]

98. Wachinger, G.; Renn, O.; Begg, C.; Kuhlicke, C. The Risk Perception Paradox-Implications for Governance and Communication of Natural Hazards. Risk Anal. 2013, 33, 1049-1065. [CrossRef] [PubMed]

99. Aerts, C.J.H.J. A Review of Cost Estimates for Flood Adaptation. Water 2018, 10, 1646. [CrossRef]

100. Hansson, R.O.; Noulles, D.; Bellovich, S.J. Knowledge, Warning, and Stress: A Study of Comparative Roles in an Urban Floodplain. Environ. Behav. 1982, 14, 171-185. [CrossRef]

101. Hudson, P.; De Ruig, L.T.; de Ruiter, M.C.; Kuik, O.J.; Botzen, W.J.W.; Le Den, X.; Persson, M.; Benoist, A.; Nielsen, C.N. An Assessment of Best Practices of Extreme Weather Insurance and Directions for a More Resilient Society. Environ. Hazards 2020, 19, 301-321. [CrossRef]

102. Kunreuther, H.; Pauly, M. Neglecting Disaster: Why Don't People Insure Against Large Losses? J. Risk Uncertain. 2004, 28 , 5-21. [CrossRef]

103. Raschky, P.A.; Schwarze, R.; Schwindt, M.; Zahn, F. Uncertainty of Governmental Relief and the Crowding out of Flood Insurance. Environ. Resour. Econ. 2013, 54, 179-200. [CrossRef]

104. Roder, G.; Hudson, P.; Tarolli, P. Flood Risk Perceptions and the Willingness to Pay for Flood Insurance in the Veneto Region of Italy. Int. J. Disaster Risk Reduct. 2019, 37, 101172. [CrossRef]

105. Suykens, C.; Priest, S.J.; van Doorn-Hoekveld, W.J.; Thuillier, T.; van Rijswick, M. Dealing with Flood Damages: Will Prevention, Mitigation, and Ex Post Compensation Provide for a Resilient Triangle? Ecol. Soc. 2016, 21, 1. [CrossRef]

106. Pham, N.T.T.; Nong, D.; Garschagen, M. Farmers' Decisions to Adapt to Flash Floods and Landslides in the Northern Mountainous Regions of Vietnam. J. Environ. Manag. 2019, 252, 109672. [CrossRef] [PubMed]

107. Thieken, A.H.; Petrow, T.; Kreibich, H.; Merz, B. Insurability and Mitigation of Flood Losses in Private Households in Germany. Risk Anal. 2006, 26, 383-395. [CrossRef] [PubMed]

108. Frantál, B.; Malý, J. Close or Renew? Factors Affecting Local Community Support for Rebuilding Nuclear Power Plants in the Czech Republic. Energy Policy 2017, 104, 134-143. [CrossRef]

109. Greer-Wootten, B. Context, Concept and Consequence in Risk Assessment Research: A Comparative Overview of North American and European Approaches in the Social Sciences. In Society, Technology, and Risk Assessment; Conrad, J., Ed.; Academic Press: New York, NY, USA, 1980; pp. 67-101.

110. Sjöberg, L.; Moen, B.-E.; Rundmo, T. Explaining Risk Perception. An. Evaluation of the Psychometric Paradigm in Risk Perception Research; Rotunde Publikasjoner, Norwegian University of Science and Technology, Department of Psychology: Trondheim, Norway, 2004.

111. Slovic, P. Trust, Emotion, Sex, Politics, and Science: Surveying the Risk-Assessment Battlefield. Risk Anal. 1999, $19,689-701$. [CrossRef]

112. Wallace, J.W.; Poole, C.; Horney, J.A. The Association between Actual and Perceived Flood Risk and Evacuation from Hurricane Irene, Beaufort County, North Carolina. J. Flood Risk Manag. 2016, 9, 125-135. [CrossRef]

113. Weinstein, N.D. Effects of Personal Experience on Self-Protective Behavior. Psychol. Bull. 1989, 105, 31-50. [CrossRef]

114. Mondino, E.; Scolobig, A.; Borga, M.; Di Baldassarre, G. The Role of Experience and Different Sources of Knowledge in Shaping Flood Risk Awareness. Water 2020, 12, 2130. [CrossRef]

115. Shah, A.A.; Gong, Z.; Ali, M.; Sun, R.; Naqvi, S.A.A.; Arif, M. Looking through the Lens of Schools: Children Perception, Knowledge, and Preparedness of Flood Disaster Risk Management in Pakistan. Int. J. Disaster Risk Reduct. 2020, $50,101907$. [CrossRef]

116. Burningham, K.; Fielding, J.; Thrush, D. 'It'll Never Happen to Me': Understanding Public Awareness of Local Flood Risk. Disasters 2008, 32, 216-238. [CrossRef]

117. Klemešová, K. Flood Maps in the Czech Republic: Content, Perception and Information Value. E3s Web Conf. 2016, 7. [CrossRef]

118. Gregory, G.; Loveridge, A.; Gough, J. Social and Cultural Aspects of Natural Hazards Perception and Response. N. Z. Geogr. 1997, 53, 47-54. [CrossRef] 
119. Wachinger, G.; Keilholz, P.; O’Brian, C. The Difficult Path from Perception to Precautionary Action-Participatory Modeling as a Practical Tool to Overcome the Risk Perception Paradox in Flood Preparedness. Int. J. Disaster Risk Sci. 2018, 9, $472-485$. [CrossRef]

120. Kasperson, R.E.; Renn, O.; Slovic, P.; Brown, H.S.; Emel, J.; Goble, R.; Kasperson, J.X.; Ratick, S. The Social Amplification of Risk: A Conceptual Framework. Risk Anal. 1988, 8, 177-187. [CrossRef]

121. Drabek, T.E. Understanding Disaster Warning Responses. Soc. Sci. J. 1999, 36, 515-523. [CrossRef]

122. Helweg-Larsen, M. (The Lack of) Optimistic Biases in Response to the 1994 Northridge Earthquake: The Role of Personal Experience. Basic Appl. Soc. Psychol. 1999, 21, 119-129. [CrossRef]

123. Knez, I.; Butler, A.; Ode Sang, Å.; Ångman, E.; Sarlöv-Herlin, I.; Åkerskog, A. Before and after a Natural Disaster: Disruption in Emotion Component of Place-Identity and Wellbeing. J. Environ. Psychol. 2018, 55, 11-17. [CrossRef]

124. Dimitrova, A.; Muttarak, R. After the Floods: Differential Impacts of Rainfall Anomalies on Child Stunting in India. Glob. Environ. Chang. 2020, 64, 102130. [CrossRef]

125. Mondal, S.H.; Murayama, T.; Nishikizawa, S. Assessing the Flood Risk of Riverine Households: A Case Study from the Right Bank of the Teesta River, Bangladesh. Int. J. Disaster Risk Reduct. 2020, 51, 101758. [CrossRef]

126. Jakubcová, A.; Grežo, H.; Hrešková, A.; Petrovič, F. Impacts of Flooding on the Quality of Life in Rural Regions of Southern Slovakia. Appl. Res. Qual. Life 2016, 11, 221-237. [CrossRef]

127. Wang, Z.; Wang, H.; Huang, J.; Kang, J.; Han, D. Analysis of the Public Flood Risk Perception in a Flood-Prone City: The Case of Jingdezhen City in China. Water 2018, 10, 1577. [CrossRef]

128. Colten, C.E.; Sumpter, A.R. Social Memory and Resilience in New Orleans. Nat. Hazards 2009, 48, 355-364. [CrossRef]

129. Dolák, L.; Brázdil, R.; Valášek, H. Hydrological and Meteorological Extremes Derived from Taxation Records: The Estates of Brtnice, Třebíč and Velké Meziř́íćí, 1706-1849. Hydrol. Sci. J. 2013, 58, 1620-1634. [CrossRef]

130. Knuth, D.; Kehl, D.; Hulse, L.; Schmidt, S. Risk Perception, Experience, and Objective Risk: A Cross-National Study with European Emergency Survivors. Risk Anal. 2014, 34, 1286-1298. [CrossRef] [PubMed]

131. de Koning, K.; Filatova, T.; Need, A.; Bin, O. Avoiding or Mitigating Flooding: Bottom-up Drivers of Urban Resilience to Climate Change in the USA. Glob. Environ. Chang. 2019, 59, 101981. [CrossRef]

132. Munzar, J.; Ondráček, S.; Řehánek, T. The Flood in August 1880-One of the Most Severe Natural Disasters of the 19th Century in the Ostrava Region (Czech Republic). Morav. Geogr. Rep. 2007, 15, $25-33$.

133. Munzar, J.; Deutsch, M.; Elleder, L.; Ondráček, S.; Kallabová, E.; Hrádek, M. Historical Floods in Central Europe and Their Documentation by Means of Floodmarks and Other Epigraphical Monuments. Morav. Geogr. Rep. 2006, 14, $26-44$.

134. Nordbeck, R.; Clar, C.; Fuchs, S.; Löschner, L.; Papathoma-Köhle, M.; Thaler, T.; Fischer, T. Die Bedeutung Des Demografischen Wandels Für Das Österreichische Hochwasserrisikomanagement. Osterr. Wasser Abfallwirtsch. 2020, 72, 245-251. [CrossRef]

135. Walker, G.; Burningham, K. Flood Risk, Vulnerability and Environmental Justice: Evidence and Evaluation of Inequality in a UK Context. Crit. Soc. Policy 2011, 31, 216-240. [CrossRef]

136. Hossain, B.; Sohel, S.; Ryakitimbo, C.M. Climate Change Induced Extreme Flood Disaster in Bangladesh: Implications on People's Livelihoods in the Char Village and Their Coping Mechanisms. Prog. Disaster Sci. 2020, 6, 100079. [CrossRef]

137. Tobin, G.; Ollenburger, J. Natural Hazards and the Elderly; FMHI Publications, University of South Florida, Scholar Commons: Florida, FL, USA, 1992.

138. Babcicky, P.; Seebauer, S. The Two Faces of Social Capital in Private Flood Mitigation: Opposing Effects on Risk Perception, Self-Efficacy and Coping Capacity. J. Risk Res. 2017, 20, 1017-1037. [CrossRef]

139. Rakib, M.A.; Islam, S.; Nikolaos, I.; Bodrud-Doza, M.; Bhuiyan, M.A.H. Flood Vulnerability, Local Perception and Gender Role Judgment Using Multivariate Analysis: A Problem-Based "Participatory Action to Future Skill Management" to Cope with Flood Impacts. Weather Clim. Extrem. 2017, 18, 29-43. [CrossRef]

140. Hudson, P.; Hagedoorn, L.; Bubeck, P. Potential Linkages Between Social Capital, Flood Risk Perceptions, and Self-Efficacy. Int. J. Disaster Risk Sci. 2020, 11, 251-262. [CrossRef]

141. Adnan, M.S.G.; Abdullah, A.Y.M.; Dewan, A.; Hall, J.W. The Effects of Changing Land Use and Flood Hazard on Poverty in Coastal Bangladesh. Land Use Policy 2020, 99, 104868. [CrossRef]

142. Ighile, E.; Shirakawa, H. A Study on the Effects of Land Use Change on Flooding Risk in Nigeria. Geogr. Tech. 2020, 15, 91-101. [CrossRef]

143. Yong, A.G.; Lemyre, L. Getting Canadians Prepared for Natural Disasters: A Multi-Method Analysis of Risk Perception, Behaviors, and the Social Environment. Nat. Hazards 2019, 98, 319-341. [CrossRef]

144. Gray-Scholz, D.; Haney, T.J.; MacQuarrie, P. Out of Sight, Out of Mind? Geographic and Social Predictors of Flood Risk Awareness. Risk Anal. 2019, 39, 2543-2558. [CrossRef]

145. Bubeck, P.; Wouter Botzen, W.J.; Laudan, J.; Aerts, J.C.J.H.; Thieken, A.H. Insights into Flood-Coping Appraisals of Protection Motivation Theory: Empirical Evidence from Germany and France. Risk Anal. 2018, 38, 1239-1257. [CrossRef]

146. Babcicky, P.; Seebauer, S. Collective Efficacy and Natural Hazards: Differing Roles of Social Cohesion and Task-Specific Efficacy in Shaping Risk and Coping Beliefs. J. Risk Res. 2019, 23, 695-712. [CrossRef]

147. Seebauer, S.; Babcicky, P. Trust and the Communication of Flood Risks: Comparing the Roles of Local Governments, Volunteers in Emergency Services, and Neighbours. J. Flood Risk Manag. 2018, 11, 305-316. [CrossRef] 
148. Rana, I.A.; Jamshed, A.; Younas, Z.I.; Bhatti, S.S. Characterizing Flood Risk Perception in Urban Communities of Pakistan. Int. J. Disaster Risk Reduct. 2020, 46, 101624. [CrossRef]

149. Imran, M.; Sumra, K.; Mahmood, S.A.; Sajjad, S.F. Mapping Flood Vulnerability from Socioeconomic Classes and GI Data: Linking Socially Resilient Policies to Geographically Sustainable Neighborhoods Using PLS-SEM. Int. J. Disaster Risk Reduct. 2019, 41, 101288. [CrossRef]

150. Lasage, R.; Veldkamp, T.I.E.; de Moel, H.; Van, T.C.; Phi, H.L.; Vellinga, P.; Aerts, J.C.J.H. Assessment of the Effectiveness of Flood Adaptation Strategies for HCMC. Nat. Hazards Earth Syst. Sci. 2014, 14, 1441-1457. [CrossRef]

151. Hudson, P.; Botzen, W.J.W. Cost-Benefit Analysis of Flood-Zoning Policies: A Review of Current Practice. Wires Water 2019, 6, e1387. [CrossRef]

152. Mishra, S.; Mazumdar, S.; Suar, D. Place Attachment and Flood Preparedness. J. Environ. Psychol. 2010, 30, 187-197. [CrossRef]

153. Lee, W.-S.; Selart, M. The impact of emotions on trust decisions. In Handbook on Psychology of Decision-Making; Moore, K.O., Gonzalez, N.P., Eds.; Nova Science Publishers, Inc.: New York, NY, USA, 2012.

154. Menges, L. The Emotion Account of Blame. Philos. Stud. 2017, 174, 257-273. [CrossRef]

155. Izard, C.E. Emotion Theory and Research: Highlights, Unanswered Questions, and Emerging Issues. Annu. Rev. Psychol. 2009, 60, 1-25. [CrossRef]

156. Loewenstein, G.F.; Weber, E.U.; Hsee, C.K.; Welch, N. Risk as Feelings. Psychol. Bull. 2001, 127, 267-286. [CrossRef]

157. Lindell, M.K.; Hwang, S.N. Households' Perceived Personal Risk and Responses in a Multihazard Environment. Risk Anal. 2008, 28, 539-556. [CrossRef]

158. Thongs, G. Integrating Risk Perceptions into Flood Risk Management: Trinidad Case Study. Nat. Hazards 2019, 98, 593-619. [CrossRef]

159. Horney, J.A.; MacDonald, P.D.M.; Van Willigen, M.; Berke, P.R.; Kaufman, J.S. Individual Actual or Perceived Property Flood Risk: Did It Predict Evacuation from Hurricane Isabel in North Carolina, 2003? Risk Anal. 2010, 30, 501-511. [CrossRef]

160. Lindell, M.K.; Perry, R.W. Household Adjustment to Earthquake Hazard: A Review of Research. Environ. Behav. 2000, 32, 461-501. [CrossRef]

161. Babcicky, P.; Seebauer, S. Unpacking Protection Motivation Theory: Evidence for a Separate Protective and Non-Protective Route in Private Flood Mitigation Behavior. J. Risk Res. 2019, 22, 1503-1521. [CrossRef] [PubMed]

162. Richert, C.; Erdlenbruch, K.; Figuières, C. The Determinants of Households' Flood Mitigation Decisions in France-on the Possibility of Feedback Effects from Past Investments. Ecol. Econ. 2017, 131, 342-352. [CrossRef]

163. Poussin, J.K.; Botzen, W.J.W.; Aerts, J.C.J.H. Factors of Influence on Flood Damage Mitigation Behaviour by Households. Environ. Sci. Policy 2014, 40, 69-77. [CrossRef]

164. Ivory, V.C.; Stevenson, J.R. From Contesting to Conversing about Resilience: Kickstarting Measurement in Complex Research Environments. Nat. Hazards 2019, 97, 935-947. [CrossRef]

165. Karagiorgos, K.; Thaler, T.; Heiser, M.; Hübl, J.; Fuchs, S. Integrated Flash Flood Vulnerability Assessment: Insights from East Attica, Greece. J. Hydrol. 2016, 541, 553-562. [CrossRef]

166. Pelling, M.; Uitto, J.I. Small Island Developing States: Natural Disaster Vulnerability and Global Change. Glob. Environ. Chang. Part. B Environ. Hazards 2001, 3, 49-62. [CrossRef]

167. Rehman, S.; Sahana, M.; Hong, H.; Sajjad, H.; Ahmed, B.B. A Systematic Review on Approaches and Methods Used for Flood Vulnerability Assessment: Framework for Future Research. Nat. Hazards 2019, 96, 975-998. [CrossRef]

168. Disse, M.; Johnson, T.G.; Leandro, J.; Hartmann, T. Exploring the Relation between Flood Risk Management and Flood Resilience. Water Secur. 2020, 9, 100059. [CrossRef]

169. Bunch, M.J.; Pathan, S.; Battaglia, A.G.; Greer-Wootten, B.; Mascoll, A.; Russell, T.; Folkema, J. Quantifying Community Resilience in South Sudan: The FEED Project (Fortifying Equality and Economic Diversification). Ecol. Soc. 2020, 25. [CrossRef]

170. Greer-Wootten, B. The Role of General Systems Theory in Geographic Research; York University, Department of Geography: Toronto, ON, Canada, 1972.

171. Holling, C.S. Understanding the Complexity of Economic, Ecological, and Social Systems. Ecosystems 2001, 4, 390-405. [CrossRef]

172. Spielman, S.E.; Tuccillo, J.; Folch, D.C.; Schweikert, A.; Davies, R.; Wood, N.; Tate, E. Evaluating Social Vulnerability Indicators: Criteria and Their Application to the Social Vulnerability Index. Nat. Hazards 2020, 100, 417-436. [CrossRef] 